\title{
Tajwīd al-Tajrīd as Kemālpāshāzāde's Critique and Reconstruction of Tajrīd: Study and Critical Edition
}

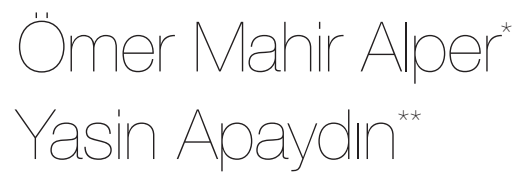

Translated by: Didar Ayşe Akbulut ***

\begin{abstract}
Kemālpāshāzāde Aḥmed Efendī (d. 940/1534), one of the most distinguished and prolific scholars and philosophers of the Ottoman era, presented systematic criticisms of some earlier foundational texts under the titles of "revision" (taghyir), "correction" (ıșläh), and "refinement" (tajwìd). His critical project incorporated a solid criticism of these seminal and influential works in linguistic, rational, and traditional sciences, both in form and in content. He also included Nașîr al-Dìn al-Ṭūsìs (d. 672/1274) Tajrìd al-ítiqād in this project. In his Tajwìd, Kemālpāshāzāde rewrote this work and wrote a commentary upon it, namely, Sharh Tajwìd al-Tajrìd. His interest in Tajrìd was not limited to these two, for in addition to a separate commentary (Sharh al-Tajrīd) he also wrote superglosses on some glosses of Tajrïd, such as Hiāshiya li-Hāshiyat al-Jalāl. So far, neither his general project nor these two works have attracted sufficient scholarly interest. In this article, we focus on Kemālpāshāzāde's studies on Tajrìd and present a detailed study of Tajwid, as well as - and for the first time - its critical edition based on all of the extant manuscript copies. Thus, the article is in four parts: The Ottoman Tajrìd Tradition: From Tajrìd to Tajwìd, Kemālpāshāzāde's Studies on Tajrīd, Kemālpāshāzāde's Critique on Tajrìd: Tajwìd al-Tajrīd," and Tajwìd al-Tajrìd.
\end{abstract}

Key words: theology (kalām), Ottoman thought, Kemālpāshāzāde, Tajwìd al-Tajrìd, Nașîr al-Dīn al-Tuusī, Tajrïd al-itiqãd, Tajrìd tradition, Tajrïd commentaries, Tajrìd glosses.

\footnotetext{
* Prof. Dr., Istanbul University, Faculty of Theology, Department of Islamic Philosophy Correnspondance: omahir@yahoo.com

** Dr., Istanbul University, Faculty of Theology, Department of Islamic Philosophy Correnspondance: yasinapaydin@hotmail.com

*** PhD Candidate, History and Middle East Studies, Harvard University
} 


\section{Introduction}

The oeuvre of KemālpāshāzādeAhmedEfendī(d.950/1534), one of thehighly prolific scholars and philosophers of the Ottoman era, can be classified according to several criteria. For instance, his writings encompassed a range of subjects, among them metaphysics, theology, the principles of law, and Quranic exegesis, all of which can be classified in genres like commentary, gloss, and annotation. While this versatility is true for the majority of later thinkers (muta'akhkhirūn) in the Islamic tradition, in the case of Kemālpāshāzāde one more genre needs to be added: that of "revision" (taghyir) or "correction" (ıșlāh), which denotes rewriting and paraphrasing certain prominent texts in various disciplines. ${ }^{1}$ Through these efforts, he sought to modify the phrasing in a text and then present a commentary through and on it. Among his works are Taghyir al-Miftāh on al-Sakkākỉ's (d. 626/1229) al-Miftāh., ${ }^{2}$ al-Ișlāḥ wa al-ịdāḥ on Șadr alSharía's commentary on Tāj al-Sharî'a's (eighth/fourteenth century) Wiqāya, and Sharh muqaddimat Tahdhīb al-mantiq wa-l-kalām on the preface of al-Taftāzānī's (d. 792/1390) Tahdhìb all of which were authored with the goal of revising and correcting their texts. Thus, his project incorporated diverse disciplines, such as rhetoric, jurisprudence, principles of jurisprudence, and theology.

Tajwìd al-Tajrid and its commentary, ${ }^{3}$ which constitute the subject of this article, were also written within this framework of "revision and correction." The text under consideration includes a rewriting of Nașîr al-Dīn al-Ṭūsìs's (d. 672/1274) original text as well as commentary on it. Until its recent printing, it had been available only in manuscript form and so had not attracted its due attention so far. Although there are numerous commentaries and glosses on Nașīr al-Dīn al-Ṭusìss Tajrid, which was one of the main "textbooks" studied in Ottoman madrasas, such an effort of revision and correction remained unique, which further increases the significance of Kemālpāshāzāde’s work.

1 In Tezkkire-i Lațîĭ one of the earliest sources on Kemālpāshāzāde, the extent and characteristics of his scholarly output were described as follows: "He expounded and resolved the obscurities and difficulties in all of these sciences, disciplines, texts, and commentaries through his penetrating and perspicuous discernment. He also wrote a treatise in every discipline and wrote discourses in every type of science." Lațîfi, Težkire-i Lațîfi, ed., Ahmed Cevdet (Istanbul: Ikdam Mațba'ası, 1314), 80.

2 For further details on Taghyīr al-Miftāh and its edition, see Musa Alak, "Kemalpaşazâde'nin Şerhu Tağyîri'l-Miftâh Adlı Eserinin Tahkik ve Tahlili” (unpublished PhD dissertation, Marmara Üniversitesi Sosyal Bilimler Enstitüsü, Istanbul 2009).

3 In this article we present the critical edition of Kemālpāshāzāde's Tajwīd al-Tajrīd and his own commentary on it. Thus, unless specified otherwise, Tajwid refers both to the original text and the commentary. 
As mentioned before, numerous thinkers have devoted their attention to Tajrìd. One of the reasons for this interest was that it belonged to the later, mature period of al-Ṭūsìs career and thus represents his latest and most original thoughts. Moreover, it comprised the entire philosophical repertoire of its own time and alȚūsīs attempt to dispense with all of the details and interpretations that he deemed superfluous or simply mistaken. Shortly after its completion, a number of works were based on Tajrìd. The first of them was Kashf al-murād fi sharh Tajrìd al-i'tiqād written by Ibn al-Muțahhar al-Hillī (d. 726/1325), one of al-Ṭūsī's closest disciples, who had a long-lasting impact through his other philosophical works. This text, along with Shams al-Dīn al-Ișfahānī’s (d. 749/1349) commentary Tasdīd al-qawāìd fi sharh al-'aqā'id, may be considered the very first steps in the "Tajrìd tradition."

This intellectual tradition around the Tajrị was expanded by the contributions and teaching activities of scholars and philosophers, especially those who were students of al-Iṣfahānī. Scholars such as al-Bābartī (d. 786/1384), al-Jurjānī (d. 816/1413), 'Alī al-Qūshjī (d. 879/1474), al-Dawwānī (d. 908/1502), and Mīr Ṣadr al-Dīn al-Shīrāzì (d. 903/1498) can be mentioned in this context as well. Although they differed in their sectarian affiliations and intellectual inclinations, all of them helped transmit the Tajrìd as a seminal work, one that established a tradition around it over the subsequent centuries. The Tajrid literature produced within the confines of Ottoman geography constitutes a significant part of this substantial tradition that encompassed dozens of titles.

\section{From the Tajrīd to the Tajwīd: The Ottoman Tajrīd Tradition}

A number of prominent Ottoman thinkers who preceded Kemālpāshāzāde had engaged with the Tajrìd and compiled numerous texts around it. This interest may be attributed to various, the most fundamental of which was the quasi-state policy of including it in the curriculum of Ottoman madrasas. This elevated status caused its name to be lent to 20-akçe madrasas in the empire, a fact that indicates the degree of interest devoted to it during the Ottoman period. As a consequence of its extensive

4 al-Ișfahānī's commentary has come to be known as al-Sharḥ al-qadìm (The Old Commentary), thereby distinguishing it from 'Alī Qushjī's later commentary. For a list of commentaries and supercommentaries on Tajrīd, see Kātib Çelebī, Kashfal-Zunūn, ed., Şerefettin Yaltkaya and Kilisli Rıfat Bilge (Istanbul: Maarif Matbaası, 1941), I, 346-51; Sayyid Maḥmūd Mar‘ashī Najafī, Kitābshināsī-i Tajrīd ali 'tiqād, ed., 'Alī Șadrā’ī Khū'î (Qom: Kitābkhānah-'i Buzurg-i Hạnrat Âyat Allāh, 2003); Salih Günaydın, "Nasîruddîn et-Tûsî̀nin Tecrîdu'l-i'tikâd’ı Üzerine Oluşan Şerh-Hâşiye Literatürü: Türkiye Yazma Eser Kütüphanelerinden Bir Bakış," Türkiye Araştırmaları Literatür Dergisi 14, no. 28 (2016), 237-72. 
study in those madrasas, many of their graduates wrote commentaries and glosses on this work, further enriching the scholarly and philosophical discourse around it.

The exact number of Ottoman scholars who wrote commentaries or glosses on the Tajrìd has not been ascertained yet; however, some prominent names can be listed based on Ṭāşköprīzāde's (d. 968/1561) al-Shaqā’iq al-nu'māniyya and Kātib Çelebī's (d. 1067/1657) Kashf al-zunūn. Chronologically, one of the earliest works was written by Hasan Çelebī (d. 891/1486) as a gloss on the initial parts of 'Alī al-Qūshjī's commentary al-Sharh al-Jadìd. It seems that this limited work, which dealt with the Tajrīd only partially and was restricted to certain matters, has been overshadowed by his other better-known works. ${ }^{5}$

After the second half of the tenth/fifteenth century, we can observe a quantitative as well as a qualitative increase in the number of scholarly Ottoman works on the Tajrìd. The first that comes to mind is Khațîbzāde Muhyī al-Dīn Efendì's (d. 901/1496) supergloss on al-Jurjānī’s Hāshiyat al-Tajrīd, which achieved lasting fame and had an impact on many later scholars. ${ }^{6}$ Thus, in al-Shaqāiq , Ṭāşköprīzāde mentioned the Hāshiya 'alā Hāshiyat al-Tajrìd at the top of the list of Muhyì al-Dìn Efendi's works and noted that "it is a work widely circulating among the people of instruction [i.e., instructors] and students." The fame that Khațībzāde derived from this work reached as far as Iran, at that time an important center of scholarly and philosophical activity, so that scholars such as al-Dawwānī took notice of him and mentioned his name in their own works. ${ }^{7}$ Khațibzāde clearly stated that his supergloss included both affirmation and rejection of the views of al-Jurjānin, who had proved his own authority in scholarly verification and inquiry through his

5 For a manuscript copy, see Hāshiya 'ala-l-sharh al-jadìd. MS, Süleymaniye Kütüphanesi, Şehid Ali Paşa, no. 1626 , fol. 18b-29a.

6 It is related that Khocazāde (d. 893/1488) studied both Khațîbzāde and al-Dawwānīs super-glosses on al-Jurjānī's gloss on Tajrīd and disapproved of the former but prized the latter. See Țāşköprīzāde, Al-Shaqā’iq al-nu'māniyya fì 'ulamä' al-dawlat al-'uthmāniyya, ed., Sayyid Muhammad Ṭabāțabā'ì alBahbahānī (Tehran: Kitābkhānah, Mūzih wa Markaz-i Asnād, Majlis-i Shūrā-yi Islāmī, 1431 [2010]), 127. In the same vein, Mollā Luṭī (d. 900/1495) is reported to have intended to write a rebuttal against Khațībzāde's super-commentary and upon the former's execution for infidelity, Khațībzāde said that his super-commentary was saved from criticism. See Țāşköprīzāde, Al-Shaqã’iq, 249.

7 Țāşköprīzāde, Al-Shaqä’iq, 137. Unlike other manuscript copies, the Feyzullah Efendi copy includes a preface that dedicates the work to Bayezid II (r. 1481-1512). See Feyzullah Efendi, no. 1114, Millet Ktp., fol. 232a. Also, Kātib Çelebī stated that Khațîbzāde had mentioned Bayezid II's name in this work. However, the author must have added this part of dedication later on at the end, because we come across references to criticisms raised by Khațibzāde in Mollā Akhawayn's (d. 900/1494-95) supercommentary on Tajrīd, which was written earlier and dedicated to Mehmed II (r. 1444-46; 1451-81), indicating that Khațîbzāde must have written his super-commentary before Bayezid II’s reign. 
gloss on Tajrìd. ${ }^{8}$ As his rejections were rather numerous, he was targeted by later authors who sought to counter his criticisms.

Another gloss on the Tajrīd was written by a contemporary of Khațībzāde, Muhyī al-Dīn Meḥmed Efendī (d. 974/1566), who was better known as Mollā Akhawayn. As in the case of Khațîbzāde, his supergloss on al-Jurjānī's gloss on the Tajrīd was mentioned at the beginning of the list of his works in al-Shaqā'iq. ${ }^{9}$ Mollā Akhawayn dedicated his work to Mehmed II and, in the preface, stated that al-Jurjānī's gloss "comprised such subtleties that may not be comprehend by every mind, and therefore it has been subject to undue objections and inappropriate challenges presented by certain people." His aim was "to attest to the already expounded matters and answer the objections directed toward it." ${ }^{10}$ Although he referred to the objectors with anonymous designations like "'some honorable men," "some virtuous men," or "some great men," his marginal notes in a manuscript reveal that these objectors were 'Alī al-Qūshjī, Khayālì (d. 875/1470 [?]), and Khațībzāde, respectively. ${ }^{11}$

Another text that stands out in this regard is the Hāshiya 'alā Hāshiyat al-Tajrìd by Muḥyī al-Dīn Meḥmed Efendī (d. 919/1513), better known as Șamsūnīzāde, who belonged to the scholarly Sāmsūnizzāde family. As the title indicates, this was a supergloss of al-Jurjānī's gloss that, in Mecdī Efendī's (d. 999/1591) words, had attained a degree of fame that was "beyond explication and description." 12 Sāmsūnīzāde himself noted that after receiving a gift favor from Bayezid II, he has completed this work by compiling his numerous notes. ${ }^{13}$

In the work's short preface, Sāmsūnizaade stated that the science of theology occupies the first place among things that deserve to be desired in the true sense of the word. Thereafter, he expounded that al-Jurjānī's Hāshiyat al-Tajrìd was "the gist of all the conclusions derived through theoretical speculation and an epitome of all the newly acquired ideas" and hence it has attracted the special interest of the later thinkers. ${ }^{14}$ However, he added that upon reading al-Jurjānī's gloss, he had discovered a discrepancy between what was intended in al-Jurjānīs own expressions and what was expounded by later glossators. Surmising that 
there was still much to be said in this regard, he began writing this work. ${ }^{15}$ Like Mollā Akhawayn, Sāmsūnīzāde also considered and responded to the objections expressed in Khațîzzāde's gloss. On almost every page he quoted these objections and answered them, but only mentioned the objector as a certain "virtuous man" or resorted to the passive "it is said."16

Another significant work preceding Kemālpāshāzāde's study of the Tajrīd was Ḥāshiya 'alā Ḥāshiyat al-Tajrìd written by Ḥusām al-Dīn b. 'Abd al-Raḥmān (d.926/1520), alias, Husām Çelebī. This supergloss on al-Jurjāni’s gloss ends at the chapter of causation, and like the other two glossators, incorporates Khațîbzāde's objections and sought to resolve them. ${ }^{17}$

Works on the Tajrid undoubtedly cannot be limited to those mentioned here, for many others were written during this period, which corresponded to the emergence and rise of the Ottoman Empire. The sources mention other glosses written by relatively early scholars, such as Khiḍrshāh Mantashawī (d. 853/1449), Khayālī, and Abū al-Wafā Muṣliḥ al-Dīn Mușțafā (d. 896/1491) as well.

In sum, before Kemālpāshāzāde, many Ottoman scholars both read and studied the Tajrì and the glosses on it. The efforts of explanation and commentary around this work started as partial glosses, as in the case of Hasan Çelebỉs supergloss, and later developed into more comprehensive texts that incorporated far more extensive discussions, as we see with Khațiibzāde's and Sāmsūnizzāde's superglosses.

\section{Kemālpāshāzāde's Studies on the Tajrīd}

Kemālpāshāzāde's interest in the Tajrīd was not limited to the Tajwìd, which constitutes this article's subject. Although the bio-bibliographic sources that list his oeuvre do not mention any title other than Tajwid, here we can draw up a new list as a result of our research in manuscript libraries and library catalogues. In this part we will review Kemālpāshāzāde's works on the Tajrìd other than the Tajwìd, and in the next part we will examine the latter work independently.

17 Several copies of this work, which is extant only in manuscript form, can be found in manuscript libraries. At the colophon of the MS. 115 in Adana İl Halk Kütüphanesi, completed in 985 AH, Ḥusām Çelebī is referred as a mudarris (teacher) at Bursa's Yıldırım Han Medresesi. See Hụsām Çelebī, Ḥāshiya 'alā Hāshiyat al-Tajrīd. MS, Adana İl Halk Kütüphanesi, no. 115, fol. 56b. 


\section{The Sharh al-Tajrìd}

A manuscript in Süleymaniye Library under the shelf mark İsmihan Sultan 429 features a subcriptio-statement on the front of the text-block, which indicates that the text is Kemālpāshāzāde's Sharḥ al-Tajrìd. It contains an incomplete commentary on the Tajrìd, including only the chapter on general matters (al-umür al-'ämma), and is bound in a volume that contains some other treatises by him. The text ends abruptly in the middle of the discussion on the superaddedness of existence to quiddity and is followed by another treatise. Although the bio-bibliographical sources state that he had written a commentary on the Tajrid, this was often associated with the Tajwid. While this commentary presents important parallels with the Tajwid and contains some similar explanations, it does not completely overlap it. Indeed, the explanations in this commentary are much more succinct compared to those in the Tajwid. Therefore, one can surmise that they constitute earlier versions of some of the thoughts that were later developed and elaborated in Tajwid.

\section{The Hậashiya muta'alliqa 'alā-l-ḥawāshī al-Tajrīdiyya ${ }^{18}$}

This work, Kemālpāshāzāde's lengthiest study on the Tajrīd, has survived in multiple manuscript copies. It is a supergloss on al-Jurjānī's gloss Hāshiyat al-Tajrīd, comprising only the introduction and the section on general matters until the topic of the "indefinability of existence." As such, it is primarily a supergloss on alJurjānī’s gloss. Nevertheless, Kemālpāshāzāde has also selected and incorporated some statements by al-Iṣfahānī, another Tajrīd commentator, together with his own annotations on them, as well as rebuttals against the objections expressed in Khațībzāde's gloss.

\section{The Hạāshiya li-ḥāshiyat al-Jalāl}

This work is found in an anthology in Süleymaniye Library under the shelf mark Carullah 1256 and seems to be the only extant copy. It consists of Kemālpāshāzāde's gloss (ta'līqa) on al-Dawwānī's gloss on 'Alī al-Qūshjī's commentary entitled alSharh al-Jadid and comprises only the subject of the superaddedness of existence to quiddity, which is part of the general matters section. Throughout the text, the author both quotes and seeks to explain 'Alī al-Qūshjî's statements. Like the previous works, this one also ends abruptly.

18 In some of the manuscript copies, the work is titled as "Hāshiya 'ala-l-hāshiyat al-qadìma 'alā Sharh alTajrīd." See Süleymaniye Kütüphanesi, Şehid Ali Paşa, no. 1626, fol. 2a. 


\section{The Hawāshi 'alā awāil Tajrīd al-muhaqqiq wa hawāshihi li-l-Sayyid al-mudaqqiq}

As the title indicates, the text is as a supergloss on the preface of "inquiring" (mudaqqiq) al-Jurjānī’s gloss on “verifying” (muhaqqiq) al-Ṭūsīs Tajrīd. Although it may seem similar to Kemālpāshāzāde's supergloss on al-Jurjānī’s gloss (number 2), a closer reading reveals that it is based on a very limited section of both the Tajrìd and the Hāshiyat al-Tajrìd and hence contains much more detailed and elaborate explanations. Another of its distinguishing features is that the beginning of the text's first page contains a statement written in a different hand and designating the text as a "treatise" (risāla). Although we prefer not to denote it as such, ${ }^{19}$ it confirms that this text was meant to be an independent work.

The text starts with an introduction that may be considered lengthy compared to the work's overall volume. ${ }^{20}$ This section relays important information: It was written upon the request of a dear friend of Kemālpāshāzāde at a time when he was teaching the Tajrìd. Upon noticing that, unlike the previous glossators who eschewed a thorough verification of the subjects, in his lectures Kemālpāshāzāde was pointing out and correcting the mistakes committed by some glossators and correcting them, this person has requested him to write a commentary. He does not explicitly identify "the (previous) glossators." Nevertheless, Kemālpāshāzāde mentioned Khațībzāde by name and explicitly stated that he found his opinions erroneous and therefore wrote this gloss to rebut them. ${ }^{21}$ This work is dedicated to a certain vizier who is mentioned only as "the venerable Pasha."

Apart from these four texts, manuscript libraries contain another work by Kemālpāshāzāde: the "Risāle fī al-'umūr al-'āmma" (Treatise on the general matters). The first chapter, "al-maqșad al-awwal fī al-'umūr al-'āmma” (The first article in the general matters), gives the impression that this too is a gloss on the Tajrid's first chapter. ${ }^{22}$ However, upon a closer reading we can suggest that this is a separate treatise by Kemālpāshāzāde on the general matters based on the Sharḥ al-Mawāqif.

19 This work's title is recorded in an inscription written in red on the top of the first page as "hadhihi risāla mu'allaqa 'alā awwal Ḥāshiyat al-Tajrīd li-l-fāḍil al-shahīr bi-Kemālpāshāzāde (This is a treatise on the first part of the Hāshiyat al-Tajrīd by the virtuous scholar known as Kemālpāshāzāde)." However, we preferred the author's own designation mentioned in the introduction referring to his work. See Kemālpāshāzāde, Hawāshi 'alā Awẩil al-Tajrīd, Süleymaniye Kütüphanesi, Şehid Ali Paşa Ktp., nr. 2737, fol. 106a. Nevertheless, this aforementioned inscription is still significant because it denotes an independent treatise in a collection of treatises.

20 This work is located between folios 106a-113b. The introduction takes up the first folio.

21 Kemālpāshāzāde, Hawāshi 'alā Awã'il al-Tajrīd, fol. 106a.

22 Multiple copies of the work are extant. For the quoted statement, see Kemālpāshāzāde, Risāla fi-l-Umūr al-'āmma, MS, Süleymaniye Kütüphanesi, Şehid Ali Paşa, no. 2838, fol. 21b. 
Indeed, tracing the statements commented upon further in the text reveals that they are derived from al-Mawāqif and its commentary Sharh al-Mawāqif.

When all of the texts presented above in their outlines are considered together, we can draw some general conclusions. First, Kemālpāshāzāde's interest in the Tajrìd was too extensive to be confined to a single text. He authored five independent texts, including the Tajwìd, each of which embody a distinct effort toward explicating and explaining the Tajrìd. Almost all of them are incomplete and mostly contain only the topics from the general matters section. This may represent his personal interests but can also be regarded as a general attitude among the scholars of the time. In fact, Tāşköprīzāde mentioned in his autobiography that he has read and taught the general matters section of both the Tajrīd and the Häshiyat al-Tajrìd. ${ }^{23}$ In a similar vein, the introduction of Kemālpāshāzāde's gloss on the Tajrìd states that he has also taught these two works and penned his own gloss within that context.

Although it is quite hard to ascertain exactly when Kemālpāshāzāde wrote each of these works, we may conclude that degree of technicality and detail in his explications increased gradually. Presumably, some notes taken in course of teaching the Tajrìd evolved into full-fledged explanations and eventually ended up with a rewriting of it.

Lastly, some annotations that were added to the same passages of the same text at different times are of great importance, as they demonstrate how the author's opinions on the respective subjects evolved. It needs to be stated that the topics related to the general matters and their problematics in particular have been deliberately treated from different aspects in all of Kemālpāshāzāde's works. Due to its importance, he had apparently been dealing with the Tajrìd for a long of time and wanted to discuss it from various perspectives to highlight several of these problematics. And as we will see in the coming part, he eventually achieved his goal of subjecting the Tajrìd to an overall criticism.

\section{Kemālpāshāzāde's Critique of Tajrīd: Tajwīd al-Tajrīd}

\section{A. The Tajwìd and the Sharh al-Tajwìd in bio-bibliographical sources}

The Tajwìd is mentioned among Kemālpāshāzāde's works in all the relevant sources, and yet they vary in describing its exact features. For instance, after 
stating that Kemālpāshāzāde had been authoring works constantly, Ṭāşköprīzāde added that "[He] has a book in the discipline of theology, consisting of a main text and a commentary, that he entitled Tajwìd al-Tajrìd." ${ }^{24}$ In Hadä'iq al-Shaqà iq , Mecdī Efendī stated "And in the discipline of theology, he composed and compiled a text and commentary entitled Tajwìd al-Tajrìd, which is vastly preferable to those compiled by his predecessors who were the lords of the place of honor and majesty (Șadr-i jāh wa Jalāl)" thus alluding to the dispute around 'Alī al-Qūshjî's al-Sharḥ alJadìd between Mìr Șadr al-Dīn al-Shīrāzī and al-Dawwānī, who came to be known as "Ṭabaqāt-i Ṣadriyya and Jalāliyya" respectively. ${ }^{25}$

In Sullam al-wușūl, Kātib Çelebī mentioned the Tajwìd al-Tajrīd only by name among Kemālpāshāzāde's works but provided no further details. ${ }^{26}$ However, in his Kashf al-ẓunūn under the article "Tajwīd fi-l-kalam," he wrote "Then it is reported that he [i.e., Kemālpāshāzāde] wrote a commentary on [Tajwīd] entitled Tajrīd, though it is more likely that [the titles] are the other way around." ${ }^{27}$ Apparently, the work had come to be known as Tajrīd al-Tajwìd among some circles; however, Kātib Çelebī pointed out that the correct title had to be Tajwìd al-Tajrìd, as already recorded by Ṭāşköprīzāde. But al-Kafawī, in his Kātāì a' lām, said that the title was Tajrìd al-Tajrìd and added that it consists of a text and a commentary. ${ }^{28}$ Similarly, Bağdatlı İsmail Pasha (1839-1920) recorded that Kemālpāshāzāde had a book of theology entitled Tajwìd fí 'ilm al-kalām as well as a commentary on it entitled al-Tajrīd fï sharh al-Tajrìd. ${ }^{29}$

The Qāmūs al-A'tām, which can be considered a relatively later source, states that Kemālpāshāzāde authored a text and a commentary named the Tajwīd and the Tajrìd, respectively. ${ }^{30}$ In his'Uqūd al-Jawhar, Cemil Bey mentioned the book as alTajwìd fī Sharh al-Tajrìd. ${ }^{31}$ Lastly Nihal Atsız, who attempted to provide a complete

25 Mecdī Efendī, Hadä’iq al-shaqāiq, 383. Mustaqīmzāde (d. 1202/1788) repeated similar statements later on. See Müstakimzâde, Devhatü’l-meşâyih, ed., Ziya Kazıcı (Istanbul: Çağrı Yayınları, 1978), 17.

26 Kātib Çelebī, Sullam al-wuṣūl ilā țabaqāt al-fuhūl, ed., Mahmud 'Abd al-Qādir al-Arnā'ūṭ (Istanbul: İslam Tarih, Sanat ve Kültür Araştırma Merkezi, 2010), I, 150.

27 Kātib Çelebī, Kashfal-Zunūn, I, 354.

28 al-Kafawī, Katāỉb a' 'ām al-akhyār min fuqahã' madhhab al-Nu'mān al-mukhtār, ed., Saffet Köse, Murat Şimşek, Hasan Özer, and Hüzeyfe Çeker (Istanbul: Maktabat al-irshād, 2017), IV, 392.

29 Bağdatlı İsmail Paşa, Hadiyyat al-Ārifinn, ed., İbnülemin Mahmud Kemal İnan and Avni Aktuç (Ankara: Milli Eğitim Bakanlığı, 1955), I, 141.

30 Şemseddin Sāmī, Ḳāmūs-ı a'tām (Istanbul: Mihran Mațba'ası, 1306 [1889]), V, 3886.

31 Jamīl Bey, 'Uqūd al-jawhar (Beirut: Dār al-Muqtabas, 1436 [2015]), 219. However, some other sources like Osmanlı Müellifleri and Sicill-i Oșmānī do not mention Tajwīd among the works of Kemālpāshāzāde. See Bursalı Meḥmed Țāhir, Osmanlı Müellifleri (Istanbul: Mațba'a-i ‘Amire, 1333), I, 223; Mehmed Süreyyā, Sicill-i Oșmānī (Istanbul: Mațba'a-i ‘Amire, 1308), I, 224. 
list of Kemālpāshāzāde's works based on library records, cited the Tajwìd as "a critique of Nāṣir al-Dīn al-Ṭūsī's book of theology called Tajrìd al-'aqā'id."32

Considering all of these pieces of information from the relevant sources together, we may draw certain conclusions. Firstly, Kemālpāshāzāde clearly authored a book of theology consisting of a text and its commentary. Most of the sources list the text's title as Tajwìd, ${ }^{33}$ whereas the commentary's title is either Tajrìd al-Tajrìd or Tajrìd fì sharh al-Tajwìd. Other sources, however, provide only the title of the main text.

Lastly, we have to state that in another work on mental existence, Kemālpāshāzāde himself referred to the Sharḥ al-Tajwìd. While explaining the difference between "subsisting ( $q \bar{a}$ 'im) through other" and "existing (thābit) through other," he referred to this work as follows: "We have verified the difference between the two in the Sharh Tajwid al-Tajrìd in a way that resolves all doubts and confusion." ${ }^{4}$ Thus, as it becomes clear through the author's own words, the text in question was entitled Tajwìd al-Tajrīd and the commentary Sharh Tajwìd al-Tajrìd. Indeed, in the Tajwìd's very introduction, Kemālpāshāzāde referred to the text in question as Tajwìd al-Tajrìd but gave no title for the commentary. ${ }^{35}$

Lastly, all of this confusion about the work's title, in addition to the facts that only a few copies are extant and that most of them are incomplete, suggests that this particular work did not attract much interest in the scholarly circles, apparently because it is a commentary on a very limited part of the Tajīid. After all, it contains merely the subjects related to the relationship between existence and quiddity, which are treated at the beginning of the Tajrìd's first chapter on general matters.

\section{B. Content and Analysis of the Tajwìd}

According to the extant manuscripts, Kemālpāshāzāde’s Tajwīd covers al-Ṭūsī’s Tajrìd from its beginning until the subject of the "superaddedness of existence to quiddity," which is discussed in the context of general matters. Certain remarks by Kemālpāshāzāde at the beginning of the text ${ }^{36}$ indicate that his apparent goal

32 Nihal Atsız, "Kemalpaşa-oğlu'nun Eserleri," Şarkiyat Mecmuası, VII (1972), 98.

33 Indeed in one of the two manuscript copies that we predominantly relied on this critical edition the main text and commentary are named together as "Tajwìd al-Tajrìd" on the front of the textblock". See Kemālpāshāzāde, Tajwīd al-Tajrīd, MS, Bibliothèque nationale de France, AY, no. 4374, fol. 140a.

34 Kemālpāshāzāde, "Risāla fī taḥqīq al-wujūd al-dhihnī," in Majmū' rasāil 'allāma Ibn Kemāl Bāshā, ed., Hamza al-Bakrī (Istanbul: Dār al-Lubāb, 2018), VI, 91.

35 Kemālpāshāzāde, Tajwīd al-Tajrīd, MS, Bibliothèque nationale de France, AY, no. 4374, fol. $142 \mathrm{a}$.

36 For example, see Kemālpāshāzāde, Tajwīd al-Tajrīd, fol. 141b, 142a-b. 
in this study was to scrutinize al-Ṭusî̀s Tajrìd in terms of its phrasing, content, structure, and organization. As such, he intended to reconstruct the original text in a better, more proper and appropriate way and then comment on this new version. Indeed, when the book is considered in its entirety, it becomes clear that he realized these aims.

Following the layout of the Tajrìd and after making some preliminary comments and explanations on the hamdala and the salwala (invoking praises to God and blessings to the Prophet), Kemālpāshāzāde focused on al-Ṭūsìs phrase "the problems of theology" (masẩil al-kalām). Elaborating on it, he presented some introductory explications about the discipline of theology without delving into much detail. At this point, he did not touch upon earlier scholars' discussions with regard to defining and subjecting the science of theology, but simply echoed al-İji (d. 756/1355) ${ }^{37}$ by defining theology as "a science that gives competence in proving religious beliefs to someone else by way of furnishing evidences and removing doubts." Similarly, just like al- $\mathrm{Ij} \overline{\mathrm{j}} \overline{1}{ }^{38}$ he propounded that the subject matter of theology is "the known thing(s) as much as they are closely or remotely pertinent to the proofs of religious beliefs." ${ }^{39}$ Thus, Kemālpāshāzāde determined that its subject matter is a "known thing" not in an absolute sense, but rather as conditioned by its association with the proofs of religious beliefs. Hence, the emphasis on "proofs of religious beliefs" constitutes an important part of his definition of theology.

According to Kemālpāshāzāde, theology's actual purpose (al-maqșūd al-aṣlī min 'ilm al-kaläm) is "the cognizance (ma'rifa) of conditions of the provenance and the destination." Since the Tajrìd was a theological work, al-Tuusĩ had laid out two purposes explaining the conditions of the provenance and the conditions of the destination, respectively. However, the existence of provenance is established by proving the originatedness (hudüth) of the universe, which consists of substances and attributes. Hence, the states of substances and attributes need to be examined first. These states are of two types: (1) one of them is common to both of them and (2) the other is specific to only one of them. In order to deal with these two types, al-Ṭusī had preferred to open up two more purposes (i.e., chapters). Moreover, most of the discourse on the destination is based on scriptural proofs that are reported either from the Prophet, whose prophethood is confirmed by miracles, or,

39 See Kemālpāshāzāde, Tajwīd al-Tajrìd, fol. 141 b. 
according to some people, from the Imām. ${ }^{40}$ Hence, two more purposes are added to deal with prophecy and imamate. In this way, Kemālpāshāzāde established why the Tajrìd consists of six goals (or chapters) in total. ${ }^{41}$

Kemālpāshāzāde's analysis of the six purposes comprising al-Ṭusī's texts is quite similar to that of 'Alī al-Qūshjī's in his commentary entitled Sharh Tajrīd aqā'id. ${ }^{42}$ However, immediately after this analysis, he criticized 'Alī al-Qūshjī but did not mention his name. The critique is directed to the latter's remark ${ }^{43}$ that "Thus, the author [al-Ṭūsī] has necessarily composed his book in six goals." ${ }^{44}$ Kemālpāshāzāde maintained that there was no necessity at all in this regard; rather, it was done as such simply due to its being better and more appropriate ('alā wajh al-istiḥsān lā 'alā wajh al-ḍarūra). ${ }^{45}$

After this introduction, Kemālpāshāzāde started to discuss the "First Purpose," which is "About the General Matters," and provided some brief and concise explanations about their nature. What stands out here and differs from other texts is that he held that these general matters correspond to "mental entities" (al-umūr al-i'tibāriyya). ${ }^{46}$ Although he gave no reasoning for this preference, in another text he provided the following explication: "We said 'mental entities' because if they existed, they would belong to one of the already mentioned parts of [existence; i.e., Necessary Existence, substance, or attribute]. Thus, it would be appropriate to treat their states in the context of one these parts; [however, this is contrary to the very concept of general matters]." ${ }^{47}$ This explanation reveals that according to him, general matters amounted to the secondary intelligibles that are other than the three parts of external existence and yet encompass them all.

41 The six "purposes" (maqșad) in al-Ṭusî̀s Tajrīd are as follows: The First Purpose: On the General Matters," "The Second Purpose: On the Substances and Accidents," "The Third Purpose: On Proving the Attributes and Acts of the Creator," "The Fourth Purpose: On Prophethood," and "The Sixth Purpose: On the Ultimate Destination, and the Divine Promise and Threat " The Fifth Purpose: On the Imamate." See Nașīr al-Dīn al-Ṭūsī, Tajrīd Al-ítiqāad, ed., Muhamamad Jawād al-Ḥusaynī al-Jalālī ([Qom]: Maktab al-I'lāmī al-Islāmī, 1407).

42 'Alī al-Qūshjī, Sharḥ Tajrìd al-'aqã’id, ed. Muhammad Ḥusayn al-Zāri'ī al-Rızāyī (Qom: Rāid, 1393), 71-72.

43 Ibid., I, 72.

44 This critique of Kemālpāshāzāde is indirectly aimed at Shams al-Dīn al-Iṣfahānī as well. Like 'Alī alQūshjī, Ișfahānī had stated that al-Ṭūsī had organized his work "necessarily" in six chapters. See Shams al-Dīn al-Ișfahānī, Tasdīd al-qawā'id fì sharḥ Tajrīd al-'aqā’id, ed., Khālid Ibn Hammād al-'Adwānī (Kuwait: Dār al-Diyā', 1433 [2012]), I, 170.

45 Kemālpāshāzāde, Tajwīd al-Tajrīd, fol. 142a.

46 Ibid., fol. 142b.

47 Kemālpāshāzāde, Risāla fi-l-umūr al-'amma. MS, Veliyyüddin Efendi Kütüphanesi, no 3235, fol. 17b. 
As a result, he contends, mental entities denoted such states that are not specific to one of the parts of existence, namely, the substance, attribute, or Necessary Existence. Rather they could apply to either all parts of existence, as in the case of the concept of "existence," or they could involve only substance and attribute, as in the case of the question of "being caused" (ma'ūliyya). ${ }^{48}$ Thus, mental entities or general matters included all of those states that are true either for all parts of existence or for the majority of them.

In the Tajrìd, al-Ṭusī divided the "First Goal" that is "About General Matters" into three sub-sections: "Existence and non-existence," "Quiddity and its Properties," and the "Cause and Caused." As mentioned above, based on extant copies, Kemālpāshāzāde's Tajwīd tackled the first section, but only some principal matters.

Kemālpāshāzāde started his discussion of this first section by stating that in the present text "existence and non-existence" (al-wujūd wa-l-'adam)" are actually "existent and non-existent," because for him, what is intended by the "general matters are the derivatives (al-mushtaqqāt) and those that are analogous to them (such as quiddity and cause)." However, what is investigated here as existent and non-existent are not existent and non-existent things as such, but rather "[the state of being] existent and [the state of being] non-existent." In other words, existent and non-existent are discussed "not by their essence (dhāt) but by their qualities," since the "superaddedness" and "univocity" [of existence] are also about the "quality of existence." On that account, any attempt to define the existent and non-existent is in reality an inquiry about the sense of "existing" and "non-existing." 49

Kemālpāshāzāde assumed that these demarcations and explanations are immanent in al-Ṭūsī's text and regarded them as foundational ( $q \bar{a}$ ‘ ida) for a sound discussion of existence. Within this framework, he underlined three critical subjects that were also widely discussed in the classical literature ${ }^{50}:(1)$ The superaddedness of existence to quiddity. According to him, although previous thinkers ('uqalā) have disagreed, for a truly intelligent mind ('āqil) even to engage in a debate regarding the superaddedness of existence is both superfluous and unwarranted, because it is self-evident that the concept of generation (kawn) cannot be taken to be the same as external essence. Nevertheless, the superaddedness of the concept of existent and of the sense of "generated" ( $\left.k a^{\prime} i n\right)$ are debatable; (2) Whether existence is an

\footnotetext{
48 Kemālpāshāzāde, Tajwīd al-Tajrīd, fol. 142b.

49 Ibid., fol. 143a.

50 For concise information on the sides of this debate, see al-İjī, al-Mawāqif fi 'ilm al-kalām, $46 \mathrm{ff}$.
} 
equivocal concept or not. Kemālpāshāzāde maintained that this was a matter of debate between the Ash'arīs and others, one that was founded on the disagreement regarding the first subject. Thus, he wrote: "What is mentioned with regard the first subject may be said in this regard as well"; and (3) Whether existence is said of its meanings in a "gradational" way or not. According to him, those who argued for the gradation of existence deduced this on the claim that the sense of existence obtains in individuals at various "gradations." It is clear that the "concept of existent" is indeed realized at various gradations in every individual; however, whether this is true for the "concept of existence" as well is open to debate. ${ }^{51}$

In this first section, Kemālpāshāzāde continues his inquiry into the problem of defining existence and non-existence. He first examined the various definitions suggested by theologians and philosophers as brought up in al-Ṭūsì's text and then analyzed how all of them led to circularity. Additionally, he indicated other "subtleties" and underlined other points that did or could lead to errors. Fakhr alDīn al-Rāzī (d. 606/1210), one of Kemālpāshāzāde’s most important sources, clearly played an influential role in all of these discussions. Indeed, he quoted a lengthy passage from the al-Mațālib al-'âliya by al-Rāzī, whom he referred to simply as "imām" regarding the sense, definition, and self-evidentiality of existence. ${ }^{52}$ He was not alone in drawing al-Rāzī into this debate, for al-Ișfahānī and Ibn al-Muțahhar al-Ḥillī, both of whom were among the Tajrìd's most important commentators, had also done so when defining existence and non-existence. Although al-Hillì did not mention any particular title, he included two arguments by "Fakhr al-Dīn" for invalidating the definition of existence. ${ }^{53}$ al-Ișfahānī had also stated that in the al-Mulakhkhaṣ "the Imām" had presented three proofs for the self-evidentiality of the conception of existence. ${ }^{54}$ The fact that these authors resorted to al-Rāzi in the same context is not merely due to their seeking support for their own opinions, but because al-Rāzī represented a particular position in this discussion. Therefore, al-Hillì also added that al-Ṭūsì did not approve of "Fakhr al-Dīn's" proofs for negating the definition. ${ }^{55}$

After this section, there is a rupture in the text. (In the Ms. Paris on folio 147a.) It is hard to determine conclusively whether this goes back to Kemālpāshāzāde or is

51 Kemālpāshāzāde, Tajwìd al-Tajrìd, fol. 143a-b.

52 Ibid., Tajwìd al-Tajrìd, fol. 144b.

53 Ibn al-Muțahhar al-Ḥillī, Kashf al-murād fī sharh Tajrīd al-ítiqād (Beirut: Mu'assasat al-A'lamī lilMațbū'āt, 1408 [1988]), 3.

54 al-Iṣfahānī, Tasdìd al-qawāiid fì sharḥ Tajrìd, 186.

55 al-Hịllī, Kashf al-murād fï sharḥ Tajrìd al-i'tiqād, 3. 
due to a complication in the course of transmitting the text. In any case, after this break Kemālpāshāzāde presents a new subject: the univocity of existence. Here, often engaged in explications (taqrï), he pointed out the relationship between breaking existence down into parts and its univocity. Accordingly, those who reject its univocity have to reject its parts of existence, such as the Necessary, substance, and attribute as well. Since this partition is a consequence of the univocity of existence, "it is impossible to reject the principle while accepting the consequence $\left(\right.$ far $\left.^{6}\right) .{ }^{\text {"6 }}$ Kemālpāshāzāde also recorded that Abū al-Ḥasan al-Ash'arī (d. 324/93536) and the Mu'tazilī scholar Abū al-Husayn al-Bașrī (d. 436/1044) had maintained a contradictory view on this subject, which has been already recorded in multiple distinct sources. ${ }^{57}$ Significantly, here Kemālpāshāzāde wrote: "Abū al-Ḥasan alAsh'arī, who is from us (minnā)." ${ }^{58}$ It would be more appropriate to interpret "from us" as referring to "ahl al-sunna" in general, rather than to Ash'arism specifically.

The Tajwid'slast part-running parallel to the Tajrid-is about the superaddedness of existence to quiddity. Like al-Hillìn ${ }^{59}$ and al-Ișfahānī, ${ }^{60}$ Kemālpāshāzāde regards the superaddedness of existence as a consequence of the fact that existence is a concept attached to all existing quiddities univocally. He stated that there was no disagreement about the superaddedness of absolute existence, ${ }^{61}$ for the dispute arose when it came to the superaddedness of specific existence ( $f_{\bar{i}}$ ziyādat al-wujūd al-khāṣs). Though "for those who reject the absolute existence, it is not quite possible to argue for the superaddedness of existence to quiddity." 62

At this point, he followed the Tajrìd's layout and thus claimed and demonstrated the superaddedness of existence through various arguments. The first of them (I) is as follows: (A) Existence is true of the existent quiddities univocally. If it was not superadded to quiddities, then it would be identical to these quiddities. If existence were identical with quiddity, then all quiddities would be unified. If existence is

Kemālpāshāzāde, Tajwīd al-Tajrìd, fol. 148b.

At this point, Ișfahānī wrote: "The majority of the verifying scholar (muhaqqiqinn) agreed that existence is said of all existents univocally. Ash'arī, however, is opposed to them and propounded that for every existent, its existence is identical to its quiddity and that they (i.e., the existents) only share the name of existence. The author [Ṭūsī] shared the majority view." al-Ișfahānī, Tasdìd al-qawāid fì sharh Tajrīd al-'aqä'id, 193.

Kemālpāshāzāde, Tajwīd al-Tajrìd, fol. 148b.

al-Hillī, Kashf al-murād fì sharh Tajrīd al-i'tiqād, 5.

al-Ișfahānī, Tasdīd al-qawā'id fì sharh Tajrīd al-'aqā’id, 199.

al-Ișfahānī too stated that there was not any disagreement about it except for the objection raised by al-Ash'arī and his followers. See al-Ișfahānī, Tasdīd al-qavā'id fì sharh Tajrīd al-'aqã’id, 199.

Kemālpāshāzāde, Tajwìd al-Tajrīd, fol. 148b. 
true of quiddities univocally and is identical to quiddity, then all quiddities are identical. However, this is impossible. (B) If existence were to be part of existent quiddities, then it would be part of itself (aw kāna juz'an li-nafsihì). However, this is also impossible because part of an existent is also existent, for an existent cannot subsist through a non-existent [part].

In the first part of this argument (A), Kemālpāshāzāde remained generally in accord with al-Tūsi. But in the second part (B), he adopted a different approach and changed al-Ṭūsì's phrasing. The second part (B) of al-Ṭūsī's argument reads as follows: [If existence were to be part of a quiddity], then parts of the quiddity would not be limited (lam tanhașir ajzäuhā). [To the contrary, parts of a quiddity would make up an infinite sequence.] Yet Kemālpāshāzāde subjected the central phrase of al-Ṭusī’s expression, namely, "[parts of the quiddity] would not be limited" to an extended explication. ${ }^{63}$ What is striking here is that in this discourse, to some extent he relied on 'Alī al-Qūshjī and even cited a passage ${ }^{64}$ from his work, but without mentioning the scholar's name. Apart from these, Kemālpāshāzāde also brought forward other questions and problems in this context and introduced additional considerations.

After this first argument, which is based on the univocity of existence, the non-identity of quiddities, and the principle that a thing cannot be part of itself, Kemālpāshāzāde moved on to the second argument (II) for the superaddedness of existence to quiddity. ${ }^{65}$ al-Ṭūsi had expressed this argument quite concisely as follows: Existence is superadded to quiddity "because existence and quiddity can be separated in the mind (wa li-infikākihimā ta'aqqulan)." Kemālpāshāzāde's explication of this argument is that "It is possible that we can think of existence without thinking of a particular quiddity. And at other times we can think of a quiddity without knowing its existence. Such a case cannot be conceived to be true for a thing and itself." ${ }^{66}$ He then raised and evaluated other points of criticism that can be brought against this deduction.

The third argument (III) is based on "the realization of contingency [for quiddities] (wa li-tahaqquq al-imkān)," in other words the subsistence (thubūt) [of a contingent]. Kemālpāshāzāde stated that this realization occurs in itself (in nafs

\footnotetext{
63 Ibid., fol. 149a-b.

64 Cf. 'Alī al-Qūshjī, Sharḥ Tajrīd al-'aquảid, I, 99-101.

65 See Kemālpāshāzāde, Tajwīd al-Tajrīd, fol. 150a.

66 Ibid., fol. 150a.
} 
al-amr) and formulated, in a way that resembles 'Alī al-Qūshjī's expressions, ${ }^{67}$ how the realization of contingency in itself indicates the superaddedness of existence: "Among the existents there are also contingent existents. If existence were not to be superadded to quiddity, then there would be no contingent existent, because contingency denotes the equal relation of the quiddity to existence and nonexistence. If existence were to be the essence of quiddity, such an equality [i.e., equal relation] would be unthinkable." ${ }^{68}$ According to Kemālpāshāzāde, this reasoning is about common existence and therefore does not demonstrate that specific existence is also superadded to quiddity.

The fourth argument (IV) is based on the meaningfulness of predicating existence on quiddity (wa [li-]fā'idat al-ḥaml). According to Kemālpāshāzāde, "Existence's predication on quiddity is meaningful, so it renders a new meaning. However, predicating something on itself cannot be meaningful at all. Similarly, when considered insightfully, predicating part of a thing on this thing does not render any meaning either. But the predication of existence is not such (i.e., meaningless)." ${ }^{9}$ He added that this explication was in accord with al-Sayyid alSharīf al-Jurjānī's (d. 816/1413) relevant comments in the Sharh al-Mawāqif ${ }^{70}$ and hence when understood as such, he maintained that al-Ṭusī's expression of "wa [li-] fä'idat al-haml" (for the meaningfulness of predication) needs to be regarded as a separate argument.

Kemālpāshāzāde insisted that in the Tajrīd, this phrase constitutes as a separate argument. In this context, his reference to al-Jurjānī contains a criticism that is directed toward other interpretations of it. This problem can be epitomized as follows: Should we understand "wa [li-]fä'idat al-ḥaml" as a separate proof, or should it be understood together with the following phrase: "wa [li]alḥāja ilā-l-istidlāl" (and for the need of proving)? Like al-Hillì, ${ }^{71}$ Kemālpāshāzāde also argued that these were two separate arguments and have to be understood independently. However, 'Alī Qūshjī (and even al-Iṣfahānī̄ ${ }^{72}$ ) regarded this as a single argument and considered it as a whole that reads "wa [li-]fä'idat al-ḩaml wa [li]al-hạjat ilā-l-istidlāl" (for the meaningfulness of predication and for the need of 
proving). ${ }^{73}$ Kemālpāshāzāde claimed that "wa [li]al-ḥājat ilā-l-istidlāl" constituted a fifth argument (V) and, therefore, it is unnecessary to connect it with the meaningfulness of the predication of existence on quiddity and, as such, to run it together with the former argument. He said that "whoever conceived that these two make up a single argument together has indeed misconceived."74 thus, criticizing 'Alī al-Qūshjī (and indirectly al-Ișfahānī) without mentioning his name. So, the explication of this fifth argument is that "We need a proof in order to know the existence of a quiddity; however, the subsistence of its essential qualities (dhātī) is evident." Kemālpāshāzāde added that at this point someone might object that this fifth argument was also inconclusive and summarized this potential argument's objection as follows: "The need for a proof is valid only for certain matters, and it may be due to the fact that these matters were not conceived of truly. ${ }^{75}$

The last argument (VI) that demonstrated the superaddedness of existence to quiddity is that "the negation of contradiction is based on the negation of the compoundness of the Necessary [Existent] (wa li-intifā al-tanākud wa tarakkub alwājib)." Like al-Ișfahānī ${ }^{76}$ and 'Alī al-Qūshjī, ${ }^{77}$ and unlike al-Hillīi, Kemālpāshāzāde regarded al-Ṭūsīs words of "wa li-intifā al-tanākud wa tarakkub al-wājib" as a single argument. However, al-Hillī contended that "wa li-intifā al-tanākuḍ" (and for the negation of contradiction) and "wa tarakkub al-wäjib" (the compoundness of the Necessary [Existent]) denoted two separate arguments. Thus, the former phrase made the sixth argument and the latter one indicated the seventh argument. ${ }^{78}$

Again, in a way unlike al-Ḥillī and similar to 'Alī al-Qūshjīi ${ }^{79}$ Kemālpāshāzāde provided the following explication for this last argument: Both of these errors (i.e., contradiction and the compoundness of the Necessary [Existent]) are implied when existence is not considered as superadded to quiddity, because if existence is not superadded to quiddity then it has to be identical to it. In that case, the first error [i.e., contradiction] arises, for in that case an expression such as "Black is not existent" means "Black is not black" [which elicits a contradiction, i.e., judging two contraries as equal]. When "not existent" is said of a thing, it has to negate the 
existence of this thing; however, in that case we have assumed that existence is identical to "black." When we deny the superaddedness of existence to quiddity, the second option is that existence is part of quiddity. In that case, the second error (i.e., the compoundness of the Necessary [Existent]) is implied, because if that were the case, then existence would be part of the Necessary [Existent] as well, [thus making the Necessary (Existent) compound, which is not true]." 80 According to Kemālpāshāzāde, the following objection can be raised against this argument (which also appears in 'Alī al-Qūshjî's work ${ }^{81}$ ): "What is determined through this argument is that existence is not part of the unity [of the whole (kull)]; however, this does not imply that existence is external to that unity either. Therefore, this argument cannot elicit conclusively that existence is superadded to unitary existence. ${ }^{82}$

Kemālpāshāzāde's analysis of these six arguments completes his Tajrīd. Based on the foregoing overview, one can see that he has verified the matters that al-Ṭusi dealt with in his Tajrìd within the framework of the scholarly and philosophical tradition that he himself has inherited. In doing so, he referred to certain significant names like al-Rāzī and al-Jurjānī either directly or, as in the case of alHillī and 'Alī al-Qūshjī, through indirect allusions. Also evident in his Tajwìd is use of a critical approach as a concomitant of the general method of "verification" to reconstruct and comment upon by reassessing the phraseology, organization, and content of al-Tūsìs Tajrīd. Certain remarks by 'Alī al-Qūshjīin his commentary on the Tajrìd constitute an especially important subject for this critical reassessment. Nevertheless, it would not be incorrect to claim that 'Alī al-Qūshjī, rather than alIșfahānī, constituted a significant source for this work of Kemālpāshāzāde.

Kemālpāshāzāde's way of explicating certain laconic expressions and arguments made by al-Ṭūsī in the Tajrīd also needs to be highlighted. He has explicated and reformulated almost all of al-Ṭūsì's arguments regarding the above-mentioned subjects. This attitude must have been informed by 'Alī al-Qūshjī, but maybe even more so by al-Hillīi. But Kemālpāshāzāde did not confine himself to merely analyzing the problems and arguments related to them, for he also added potential challenges and objections that could be raised against these arguments. The name behind these objections was partly 'Alī al-Qūshjī; however, unlike 'Alī al-Qūshjī's approach in his commentary on the Tajrīd, Kemālpāshāzāde was rather reluctant to respond to these objections. 
As a concluding remark, we can state that although Kemālpāshāzāde compiled his Tajwìd by drawing on the commentaries of al-Iṣfahānī, 'Alī al-Qūshjī, and alHillīi, it is nevertheless quite distinct for both its structure and content. This can be attributed to the fact that it is not a commentary on Tajrìd in the traditional sense, but rather belongs to a new genre of "refinement" (tajwìd). Alhough its author's scholarly and philosophical preferences must have been consequential, more extensive and compared studies are needed to determine this work's place within the Tajrìd tradition exactly and accurately.

\section{Manuscript Copies of the Tajwìd al-Tajrìd}

Both the Tajwìd and the Sharh al-Tajwìd existed only in manuscript form until recently, when they were published within a collection of Kemālpāshāzāde's treatises. ${ }^{83}$ According to the editor's introduction, the published version was edited by collating three incomplete copies. He also noted that despite the incompleteness of the available copies, the edition was prepared due to the work's significance and in the hope that a complete copy would eventually be found. ${ }^{84}$

This critical edition was based on three out of the six manuscript copies presented below, while the two most complete copies and another one that has a date of copy have been disregarded. Hence, the edition did not cover approximately one-fifth of the whole text that is available only in these disregarded manuscript copies. Moreover, since this edition omitted the two most complete copies, some of the additional information found in them - the author's annotations in the Paris copy and some marginal notes by a mudarris (teacher) in the Bursa copy - and is directly related to the matters discussed is missing.

In addition to those shortcomings, the published edition is also marred by some misreadings. Taking the Atıf Efendi copy as the only source for most parts has contributed to this. One can assume that when some of the problematic passages are collated with the Paris and Bursa copies, most of the mistakes can be eliminated. These and some other reasons have necessitated a new critical edition of this work. This present edition presents the Tajrìd and the Sharh al-Tajwìd to the scholarly world in the most complete way possible, based on the available manuscript copies.

83 Kemālpāshāzāde, "Sharḥ Tajwid al-Tajrīd," in Majmū' rasāill 'allāma Ibn Kemāl Bāshā, ed., Hamza alBakrī (Istanbul: Dār al-Lubāb, 2018), VII, 325-52.

84 Kemālpāshāzāde, "Sharḥ Tajwid al-Tajrīd," VII, 322. Remarkably, the editor provided the name of the collection to which the manuscripts belong, but not the shelf numbers. 


\section{Bibliothèque nationale de France (Paris), AY, no. 4374, fol. 140b-151b}

One of the two relatively more complete copies. it is bound in a volume that also includes Kemālpāshāzāde’s Taghyīr al-Miftāḥ. "Tajwīd al-tajrīd li-l-mawlā Kemālpāshāzāde" is written on top of the text. The textblock's front page provides the ownership and acquisition records made by Muḥammad Husaynī b. Mawlā Husayn Akhīzāde; Yahyā b. 'Abd al-Halīm, a mudarris at Sinanpaşa Medresesi; and Akhīzāde İbrāhīm Efendī. Another note states that a certain "Maḥmūd Efendī" has copied this work. This person is most likely Mollā Maḥmūd Efendī, who, according to another note on the front page, was the son of Akhīzāde Muhammad Husaynīs uncle.

As this copy is clearly incomplete, it is currently impossible to decide whether it represents the author's last version or not. However, the fact that the text ends with a tamma (ended) record indicates that at least the original copy used by the copyist reached only this far. This copy includes also annotations made by the author and ends with the section on "the superaddedness of existence to quiddity." Although other copies include some of the author's annotations as well, the Paris manuscript includes all of them in addition to some extra notes. All of these annotations have been indicated in the critical edition's section for footnotes.

Another feature of this copy is that the Tajwid is followed by another work that starts immediately on the next folio without any interruption. This text, which appears on folios $152 \mathrm{a}$ and $159 \mathrm{~b}$, bears certain elements suggesting that it is a continuation of the Tajwid. First of all, it has no any introductory material, such as the basmala or a preface. Secondly, its first sentence reads: "It is on the general matters, which is the first chapter (maqșad) of [the Tajrìd?]" and gives the impression that, like the Tajwìd, this text has also been written on the Tajrīd. As it stands, one can think that this is also part of the former. However, a more detailed study and a comparison with Kemālpāshāzāde's other works warrants the opposite view as well.

This second text may be a whole one or part of another text added by the copyist immediately after Tajwìd due to their similarity in subject. Two pieces of evidence support this claim. First of all, Kemālpāshāzāde already expressed his opinions on the goal (maqsad) of the Tajrīd's, which deals with the general matters, in the very first pages of Tajwid under a separate chapter. Thus, it seems highly unlikely that he would do this twice in a single text. Secondly, this second text comprises the same explanations found in his Risāla fi al-umūr al-'àmma. The only divergences are that it starts with a reference to the Tajrīd instead of the Sharh al-Mawāqif and that the above-mentioned title-sentence has been written by another hand, which may 
indicate that it is simply a mistake by a later reader. When read properly, it is clear that the statements explained are indeed from the Sharh al-Mawāqif. Thus, this text comprises of a gloss ( $t a$ 'lìqa) on the second chapter (mawqif) of Ijjìs al-Mawāqif. When these two pieces of evidence are considered together, one can argue that the Tajwid and the second pieces must be considered separate works that the copyist put together due to their similarity in subject.

We believe, however, that there is a third possibility: The extant text of the Tajwid is the author's final version and the following text is a later addition, again made by the author himself. Although a low-probability scenario, some textual and extra-textual clues do support it. First of all, the Tajwìd's discussion on general matters is rather brief and concise, perhaps because the author considered his previous and rather lengthy explanations on that subject in his Sharh al-Mawāqif as sufficient. Therefore, instead of repeating them he just added them to the Tajwid's end. A supporting extra-textual clue is that the concomitance of this work and the gloss on the general matters chapter of the Sharh al-Mawãqif is not unique to the Paris manuscript. Interestingly, in the Bursa and Atif Efendi manuscripts (presented below), both the Tajwid and this gloss come together. Although this might be mere coincidence, it is worth considering as a clue that suggests this third scenario.

Another matter that needs to be stated is that this manuscript contains a half-written page that corresponds to the author's commentary on the incomplete definition of existence. At this point, a sentence is cut in the middle and the text continues on the following folio with a new theme, namely, the univocity of existence. We cannot express a conclusive opinion on whether this was the case in the original copy as well, but the fact that this part is left vacant in the other copies - assuming that they do not stem from the same parent copy-suggests that it was the author who left it uncompleted.

In the collated edition, the Paris manuscript is indicated by (ف).

\section{2. İnebey Manuscript Library (Bursa), Genel, no. 4672, fol. 1b-10b}

This copy, which also presents a relatively complete version of the Tajwid, has not been referenced in the modern literature so far. In fact, the present authors are the first ones to have detected it. The margin of the copy's first folio contains the statement "Majmū'a min 'aqầ'id al-kalām" Relying on this note, the volume is 
catalogued under this title. During the Ottoman period, it was apparently stored in the Süleyman Paşa Library and later transferred to the İnebey Manuscript Library.

The front page contains an ownership statement of Ibrāhīm b. Mușțafā (?). The author's marginal annotations correspond completely to those in the Paris manuscript. In addition to these, other marginal annotations are signed at the end by "haqi $r$ " (the wretched one). Although we cannot know for certain to whom these notes belong, it is likely that he is the same person as indicated in the ownership statement.

There are interesting similarities between this manuscript and the Paris manuscript. As mentioned above, both manuscripts include annotations by the author. Moreover, both of them start at the same point and end with the author's commentary on the very same statements. These manuscripts and the Atif Efendi manuscript (introduced below) are interrupted at the same places throughout the text. Based on these similarities, we can think of a connection between these two copies, for it seems that one constituted the original copy for the other. Considering the additional annotations made by a reader in the Bursa manuscript, we can assume that it was copied from the Paris manuscript and that these annotations were added later.

Another significant similarity appears at the end of the text. As mentioned above, the Paris manuscript is followed by Kemālpāshāzāde's gloss on the section of general matters in his Sharh al-Mawāqif, which is catalogued as a separate work and can hardly be part of the Tajwid. This same text appears at the end of the Bursa manuscript as well. The tamma record for the Tajwid appears in the middle of the folio $10 \mathrm{~b}$, and then a new work starts with the following statement: "Qāla al-maqșad al-awwal fi-l-umūr al-'amma" (The first chapter on the general matters). As stated above, this strengthens the possibility that the author added this second text to the Tajrìd's end.

These two copies, introduced here in a relatively detailed way, are currently the most complete of the extant ones and serve as the basis for the present edition. The following three manuscripts are more deficient.

In the collocation, this copy is indicated by $\left({ }^{\prime}\right)$.

\section{Atıf Efendi Library (Istanbul), no. 2816, folio. 184b-187b}

This manuscript is bound in a collection that includes other treatises by Kemālpāshāzāde. Like the previous copy it ends abruptly and without any record of completion in the middle of the discussion on the superaddedness of existence to 
quiddity, and the next treatise follows immediately thereafter. The catchword at the bottom of the last folio indicates that the following folio was torn off or otherwise removed from the volume at some point. Hamza al-Bakrī used this deficient copy for his earlier printed edition.

Although the Atıf Efendi manuscript features some significant differences compared to the two previously mentioned copies, here too there are cases a discussion being interrupted abruptly and the following text introducing another subject. In this copy, the lacunae are indicated with three dots that correspond to the half-written pages in the previous copies. This correspondence suggests the possibility that the author is responsible for their being left incomplete; however, the available evidence does not allow a decisive judgement on this matter.

In the collocation, this copy is indicated by $(\varepsilon)$.

\section{Topkapı Palace Museum Library (Istanbul), Revan Köşkü, no. 2022, folio. 99a-100a}

This copy, which is bound in a volume that includes other treatises by Kemālpāshāzāde, only contains the text's introductory section. At its beginning, a clause in red ink reads "Taghyīr Tajrīd al-aqā'id l-l-mawlā al-mudaqqia Kemālpāshāzāde" which suggests that the disagreement over the work's title stems from a discrepancy in the manuscripts. Indeed, this title is repeated within the text as well. In the previous two copies the work is entitled Tajwìd al-Tajrìd; here it reads Tahrīr al-'aqâ'id. Although this particular title is not found in the sources that list Kemālpāshāzāde's work, it is meaningful when taken together with his other works written within the framework of his above-mentioned revision (taghyìr) project.

Unlike all of the other copies, the Revan Köşkü manuscript bears a date of copy, for at the end of the treatise a record of completion reads: "The found part [of the work] was completed in the hands of Yūsüf b. Muhammad in Ramadan of the year 1009 [March 1601]." This statement, found in a copy written half a century after the author's death, shows that the copyist had obtained an incomplete copy.

Another feature of this copy is that it contains only some of the author's annotations (minhuwāt), which are indicated in the critical edition's section for footnotes. Based on the fact that the same concluding remarks are found in the two copies mentioned below and the correspondence of the author's annotations, 
as well as the fact that they also comprise only the introductory section, suggests that their source was the Revan Köşkü copy.

In the collocation, this copy is indicated by $(\jmath)$.

\section{Süleymaniye Library (Istanbul), Bağdatlı Vehbi, no. 2041, folio. 251b-252a}

This copy, which is found in an anthology that contains various other treatises, is heavily deficient compared to the previous manuscripts. It also features only the introduction and ends with the statement: "With the help and divine assistance of God, the found part [of the book] has been completed." The clauses that are commented upon are written in a different color and thus distinguished from the rest of the text.

In the collocation, this copy is indicated by $(\varphi)$.

\section{Murat Molla Library (Istanbul), no. 1834, folio. 341a-342a}

This copy, found in an anthology, is quite similar to the previous copy, except for some minimal differences. The points highlighted for the previous copy are valid for this one as well. Considering the similarities between the last three manuscripts, we can assert that one of them should have constituted the source for the other two.

In the collocation, this copy is indicated by ( $\curvearrowright$ ).

\section{The Method of Critical Edition}

For the critical edition, we have followed the ISAM Tahkikli Neşir Kılavuzu (ISAM Manual of Critical Edition). Since there is no autographed copy or any copy that has been read together with the author, we had to choose between the two most complete copies, namely, the Paris (ف) and the İnebey (أ ) manuscripts. As we preferred the former due to its greater accuracy, whenever we preferred the latter, we indicated this in the footnote along with other differences. The edition includes all of the marginal notes and the author's annotations, and the differences that occur in the incomplete copies are indicated. The various references made in the text, as well as the identity of those who made the assertions and objections, have 
been identified. The main text of the Tajwid is presented in bold font and within quotation marks, whereas the rephrased Tajwìd is given in bold font only. In order to demonstrate the differences between both texts and enable a better comparison, they are presented together at the end of the article.

\section{Bibliography}

Alak, Musa. “Kemalpaşazâde'nin Şerhu Tağyîri'l-Miftâh Adlı Eserinin Tahkik ve Tahlili." Unpublished PhD dissertation, Marmara Üniversitesi Sosyal Bilimler Enstitüsü, Istanbul 2009.

Aṣma'ī. al-Aṣma‘īyāt. Edited by Aḥmad Muhammad Shākir and 'Abd Al-Salām Hārūn. Cairo: Dār Al-Ma'ārif, n.d.

Atsız, Nihal. “Kemalpaşa-oğlu’nun Eserleri,” Şarkiyat Mecmuası, VII (1972).

Bağdatlı, İsmail Paşa. Hadiyyat al-Ārifin, I. Edited by İbnülemin Mahmud Kemal İnan and Avni Aktuç. Ankara: Milli Eğitim Bakanlığı, 1955.

Dawwānī, Jalāl al-Dīn. al-Ḥāshiya al-qadīma 'alā al-sharḥ al-jadīd. Published in Sharḥ Tajrīd al-'aqā’id. I. Edited by Muḥammad Ḥusayn al-Zāri'ī al-Rızāyī. Qom: Rāid, 1393 [1973].

Günaydın, Salih. "Nasîruddîn et-Tûsînnin Tecrîdu'l-i'tikâd'1 Üzerine Oluşan Şerh-Hâşiye Literatürü: Türkiye Yazma Eser Kütüphanelerinden Bir Bakış," Türkiye Araştırmaları Literatür Dergisi 14, no. 28 (2016): 237 72.

Ḥasan Çelebī. Hâashiya 'ala-l-sharḥ al-jadīd. MS, Süleymaniye Kütüphanesi, Şehid Ali Paşa, no. 1626.

Khātibzāde. Ḥāshiya 'ala-l-Tajrīd. MS, Millet Kütüphanesi, Feyzullah Efendi, no. 1114.

Ḥillī, Ibn al-Muțaḥhar. Kashf al-murād fì sharḥ Tajrīd al-ítiqūd. Beirut: Mu’assasat al-A'lamī lil-Maṭbū'āt, 1408 [1988].

Ḥusām Çelebī. Hāshiya 'alā Hāshiyat al-Tajrīd. MS, Adana İl Halk Kütüphanesi, no. 115.

İjī, 'Aḍud al-Dīn. al-Mawāqif fì 'illm al-kalām. Beirut: 'Ālam al-Kutub, n.d.

Iṣfahānī, Shams al-Dīn. Tasdīd al-qawā’id fì sharḥ Tajrīd al-'aqā’id, I. Edited by Khālid Ibn Ḥammād al-'Adwānī. Kuwait: Dār al-Diyā 1433 [2012].

Jamīl Bey. 'Uqūd al-jawhar. Beirut: Dār al-Muqtabas, 1436 [2015].

Jurjānī, al-Sayyid al-Shārīf. Sharḥ al-Mawaqîf. Constantinople: Dār al-Ṭibā‘ah al-Āmirah 1266.

Sharḥ al-Mawaqĩf. Constantinople: Dār al-Ṭibā‘ah al-Āmirah, 1311.

Ḥāshiya al-Tajrīd. MS, Köprülü Kütüphanesi, Fâzıl Ahmed Paşa, no. 800.

Kātib Çelebī. Kashf al-Ẓunūn 'an asāmī al-kutub wa al-funūn, I. Edited by Şerefettin Yaltkaya and Kilisli Rıfat Bilge. Istanbul: Maarif Matbaası, 1941.

, Sullam al-wușūl ilā țabaqāt al-fuhūl, I. Edited by Mahmud 'Abd al-Qādir al-Arnā'ūṭ. Istanbul: İslam

Tarih, Sanat ve Kültür Araştırma Merkezi, 2010.

Kafawī. Katā’ib a 'lām al-akhyār min fuqahā' madhhab al-Nu'mān al-mukhtār, IV. Edited by Saffet Köse, Murat Şimşek, Hasan Özer, and Hüzeyfe Çeker. Istanbul: Maktabat al-Irshād, 2017.

Kemālpāshāzāde. Hāāshiya 'alā al-Ḥāshiyat al-qadīma 'alā Sharḥ al-Tajrīd. MS Süleymaniye Kütüphanesi, Şehid Ali Paşa, no. 1626.

Risāla fĩ al-umūr al-'āmma. MS, Veliyyüddin Efendi Kütüphanesi, no 3235.

"Risāla fĩ taḥqīq al-wujūd al-dhihnī." In Majmū' rasā’il 'allāma Ibn Kemāl Bāshā, VI. Edited by Ḥamza al-Bakrī. Istanbul: Dār al-Lubāb, 2018. 
, "Sharḥ Tajwid al-Tajrīd” In Majmū' rasā’il 'allāma Ibn Kemāl Bāshā, VII. Edited by Hamza el-Bekrî, Istanbul: Dār al-Lubāb, 2018.

, Hawāshi 'alā Awāỉl al-Tajrīd. MS, Süleymaniye Kütüphanesi, Şehid Ali Paşa, no. 2737.

, Risāla fí al-Umūr al-'āmma. MS, Süleymaniye Kütüphanesi, Şehid Ali Paşa, no. 2838.

, Tajwīd al-Tajrīd. MS, Bibliothèque nationale de France, AY, no. 4374.

Tajwīd al-Tajrīd. MS, İnebey Yazma Eser Kütüphanesi, Genel, no 4672.

, Tajwìd al-Tajrīd. MS, Atıf Efendi Kütüphanesi, no. 2816.

Tajwīd al-Tajrīd. MS, Topkapı Sarayı Müzesi Kütüphanesi, Revan Köşkü, no. 2022.

Tajwīd al-Tajrīd. MS, Süleymaniye Kütüphanesi, Bağdatlı Vehbi, no 2041.

Tajwīd al-Tajrīd. MS, Murat Molla Kütüphanesi, no. 1834.

Latīfī. Težkire-i Lațîfí. Edited by Ahmed Cevdet. Istanbul: İkdam Mațba'ası, 1314.

Mecdī Efendī. Hadä’iq al-shaqā’iq. Istanbul: Dār al-Ṭibā'at al-'Āmira, 1269.

Mollā Akhawayn. Hawāshī 'alā Hāshiyat al-Tajrīd. MS, Milli Kütüphane, no. 3227.

Müstakimzâde. Devhatü'l-meşâyih. Edited by Ziya Kazıcı. Istanbul: Çağrı Yayınları, 1978.

Najafī, Sayyid Maḥmūd Mar'ashī. Kitābshināsī-i Tajrīd al-i'tiqād. Edited by 'Alī Șadrā’ī Khū'ì. Qom: Kitābkhānah-'i Buzurg-i Ḥaẓrat Āyat Allāh, 2003.

Qurashī, Abū Zayd Muhammad ibn Abī al-Khațțāb. Jamharat Ash'ār al-'Arab fì al-Jāhilīyya wa-l-Islām. Edited by 'Alī Muḥammad al-Bajāwī. Cairo: Dār Nahḍat Mișr, [1967].

Qushjī, 'Alī. Sharḥ Tajrīd al-'aqā’id, I. Edited by Muhammad Ḥusayn al-Zāri'ī al-Rızāyī. Qom: Rāid, 1393 [1973].

Sāmī, Şemseddin Ḳāmūs-ı a lām, V. Istanbul: Mihran Mațba‘ası, 1306 [1889].

Sāmsūnīzāde. Hāshiya 'alā Hāshiyat al-Tajrīd. MS, Burdur İl Halk Kütüphanesi, no. 155.

Süreyyā, Meḥmed. Sicill-i Oșmānī, I. Istanbul: Mațba‘a-i ‘Āmire, 1308.

Ṭāhir, Bursalı Meḥmed. ‘Osmānlī Müellifleri, I. Istanbul: Maṭba‘a-i ‘Āmire, 1333.

Ṭāşköprīzāde. Al-Shaqāiq al-nu'māniyya fì 'ulamä’ Al-dawlat al-'Uthmāniyya. Edited by Sayyid Muhammad Ṭabāțabā'ī al-Bahbahānī. Tehran: Kitābkhānah, Mūzih Va Markaz-i Asnād, Majlis-i Shūrā-yi Islāmī, 1431 [2010].

Ṭūsī, Nașīr Al-Dīn. Tajrīd al-i'tiqãd. Edited by Muhammad Jawād Al-Ḥusaynī al-Jalālī. [Qom]: Maktab AlI'lāmi Al-Islāmī, 1407 [1986]. 


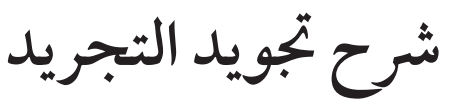 للمولى كهال باشاز اده'}

$$
\text { بسم الله الرحمن الرحيم }
$$

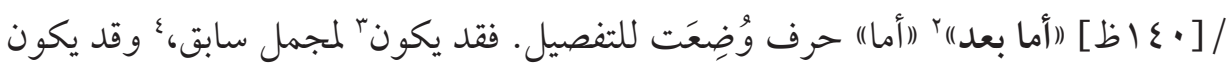

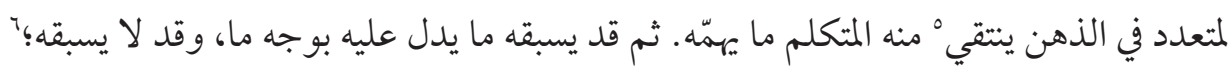

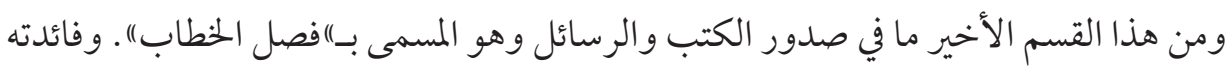

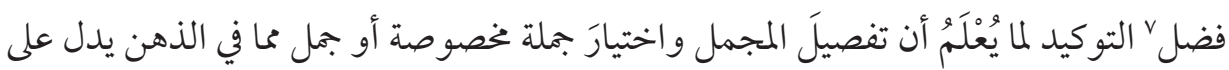
زيادة اعتناء بشأنها.

(احمد واجب الوجود) آثَ من صفاته العلى ما هو أقوى اختصاصًا به تعالى؛ فإن الوجوب الذاتي

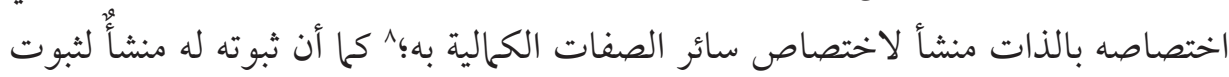

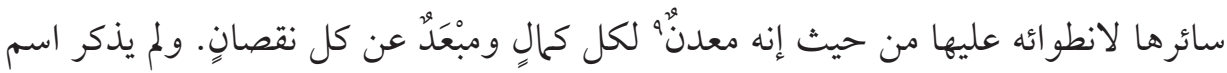

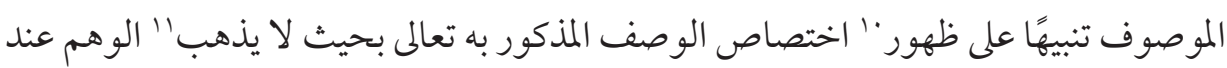

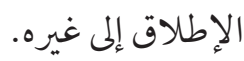

$$
\begin{aligned}
& \text { ا ب ر ر تغيير تجريد العقائد للمولى المدقق كمال باشاز اده رحمة اللّه عليه رحمة واسعة. }
\end{aligned}
$$

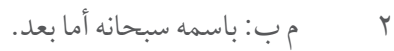

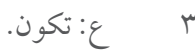

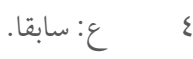

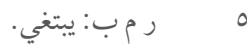

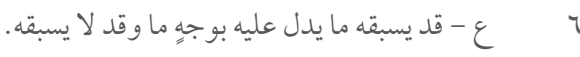

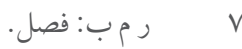

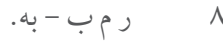

$$
\begin{aligned}
& \text { و } 9 \\
& \text { • ا وفي هامش أ: إنما قلنا على ظهور دون على قوة كما قاله الشريف الفاضل؛ لأن مدار ما ذكر من عدم ذهاب الوهم }
\end{aligned}
$$$$
\text { إلى غيره على الظهور لا على القوة كما لا يخفى، منه. }
$$

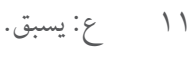


(اعلى نعحائه) التي من جملتها التوفيق بتأليف هذا الكتاب الجليل الشأن. (والصلاة على سيد

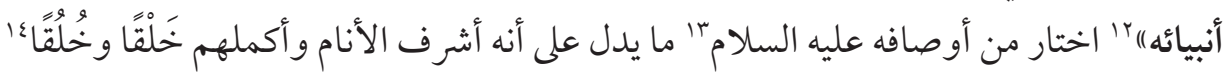

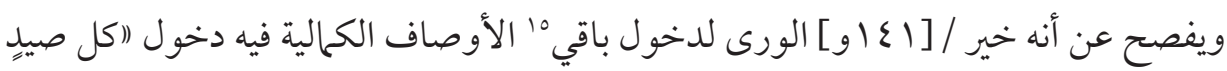
في جوف الفرى" وعدم ذكر الموصوف معه؛ لأنه كالعَلم له عليه ب' السلام. "(وعلى أكرم أحبائه) يعني من اتصف من محبوبيه" و احدًا كان أو متعددًا بزيادة الكرم في الجملة

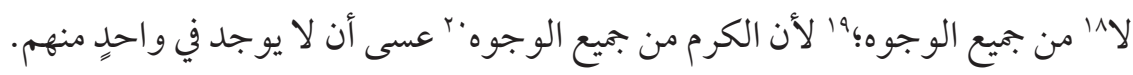

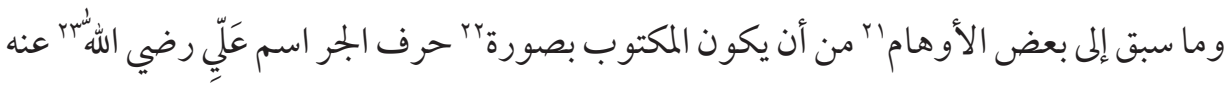

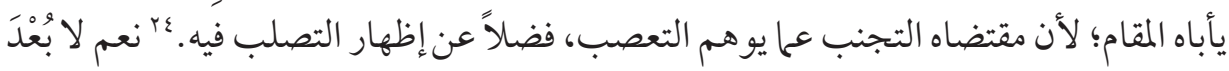

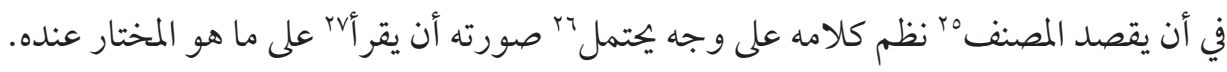

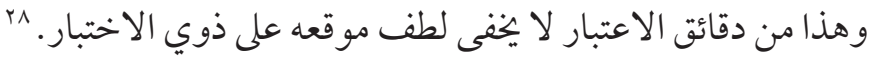

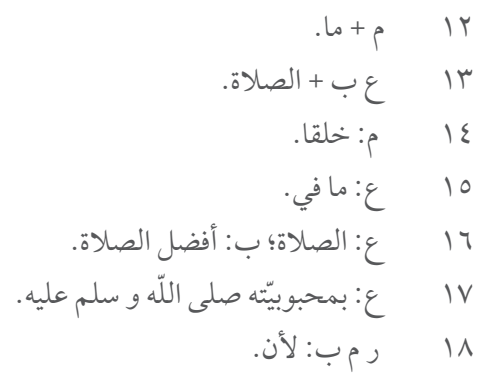

19 1 وفي هامش أر م ب: فيه تعيين لتعلق قوله في الجملة إلى الكرم ومن صرف الظرف المذكور إلى الزيادة لنقصان

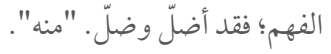

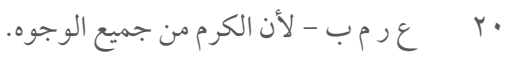

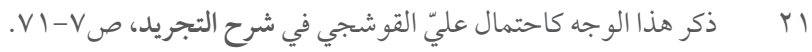
( أl

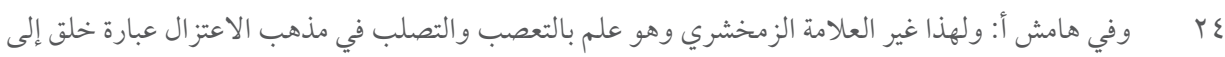

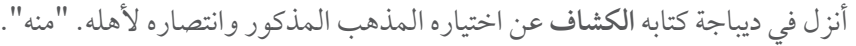

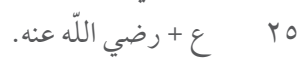

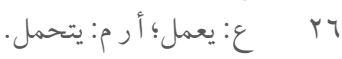
Y P P يقرأ. أ Y أ: الاختيار. 


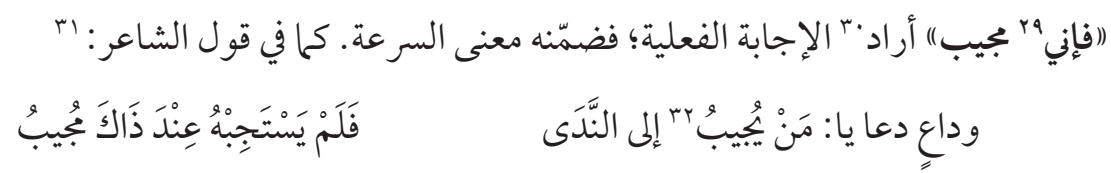

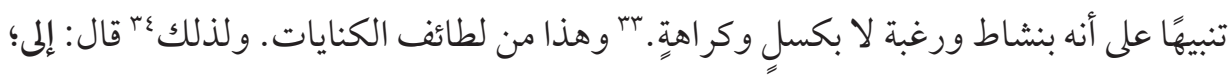

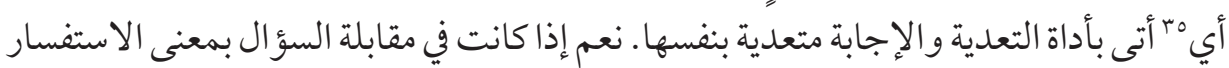

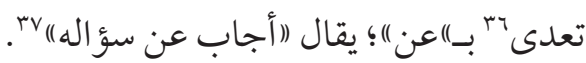

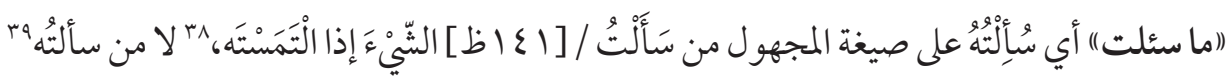

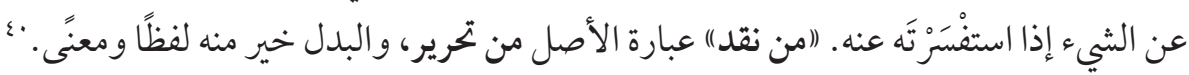

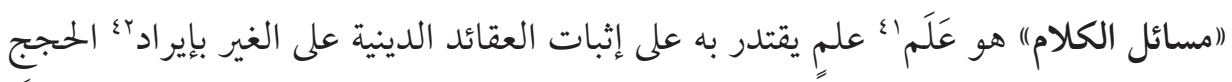

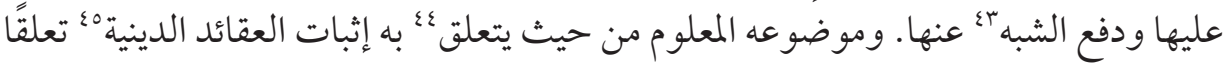
قريبًا أو بعيدًا. (ونضدها)) عبارة الأصل وترتيبها و البدل أقل حرفًا وأجلّ ظرفًا. بـ (على أبلغ

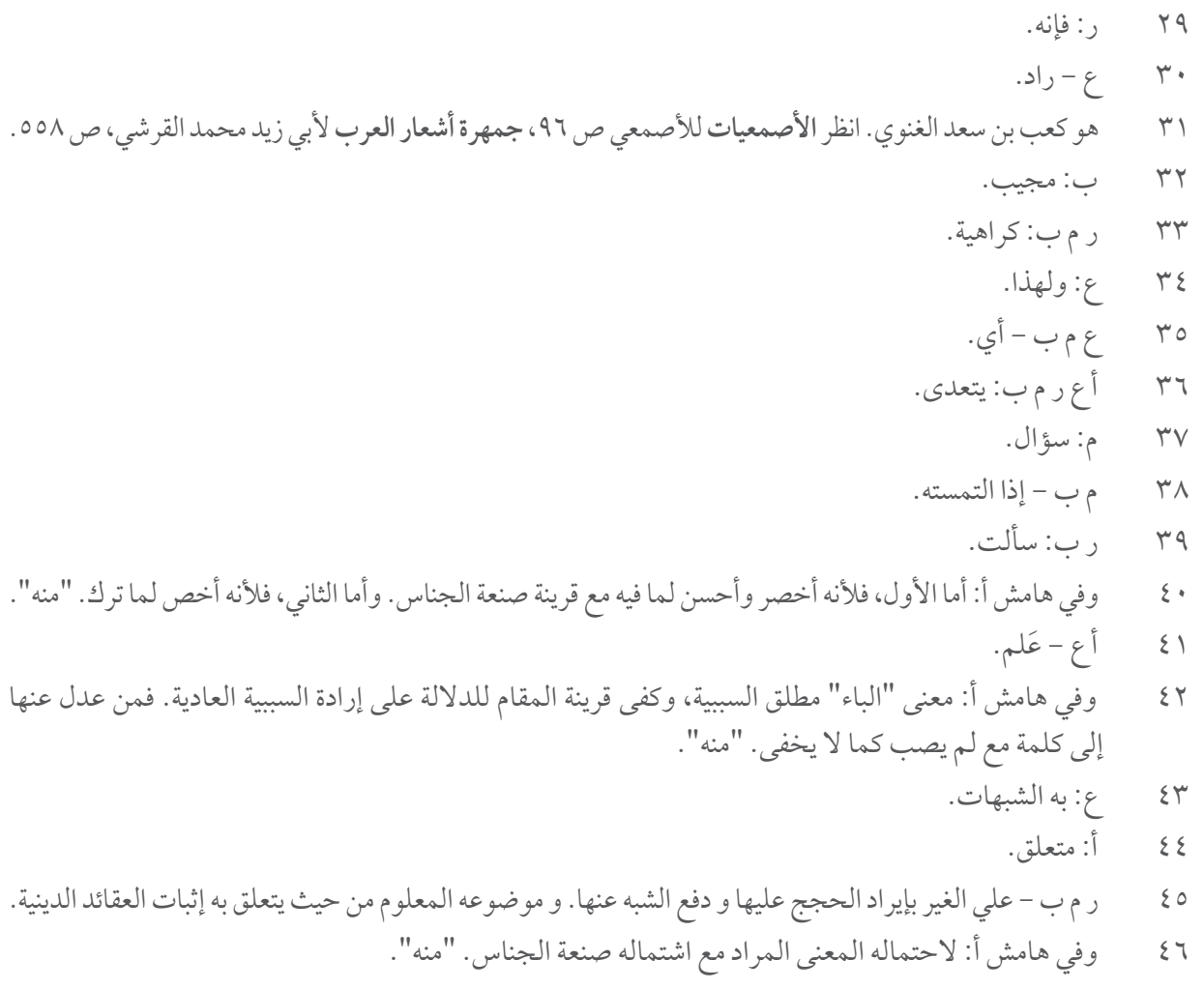


النظام) ترتيب المسائل في التجريد ع إلم يكن على أبلغ النظام كما لا يخفى على المتأمل فيه مِن ذوي

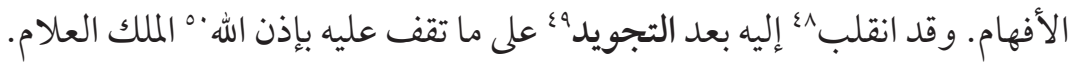

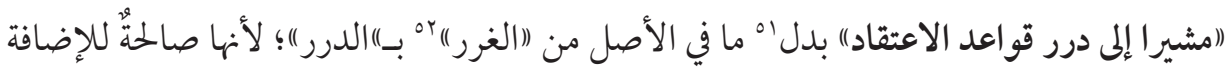

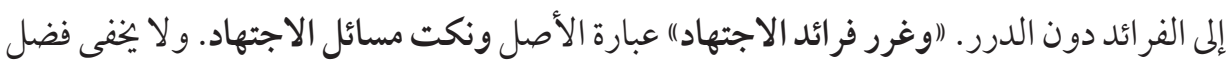

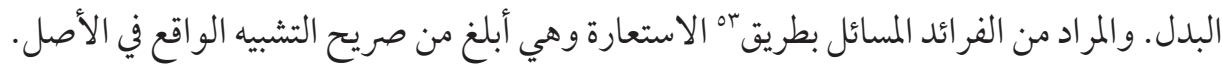

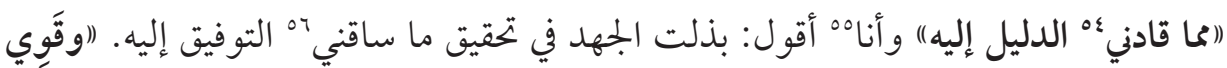

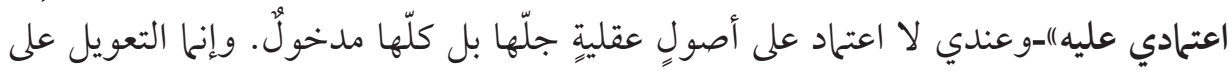
الدليل المستند على الشرع الجليل.

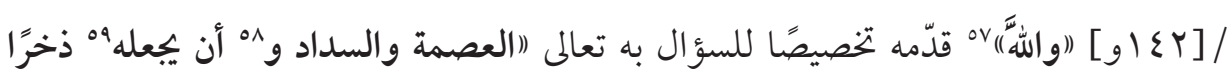

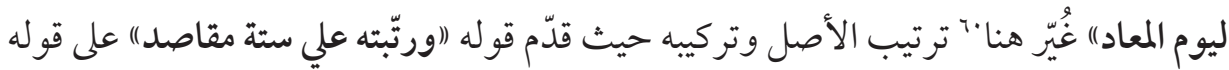

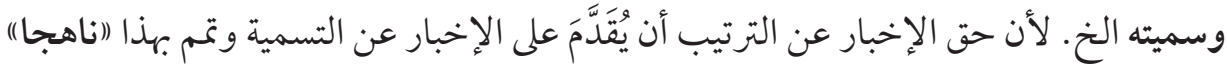

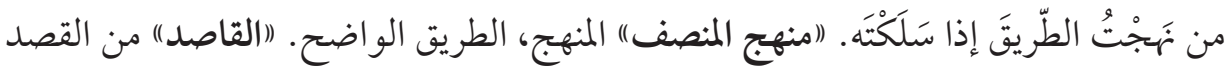

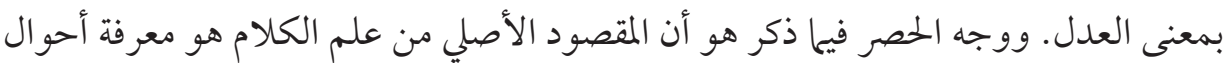

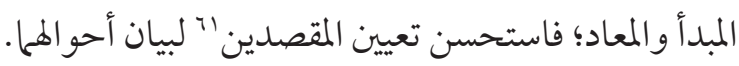

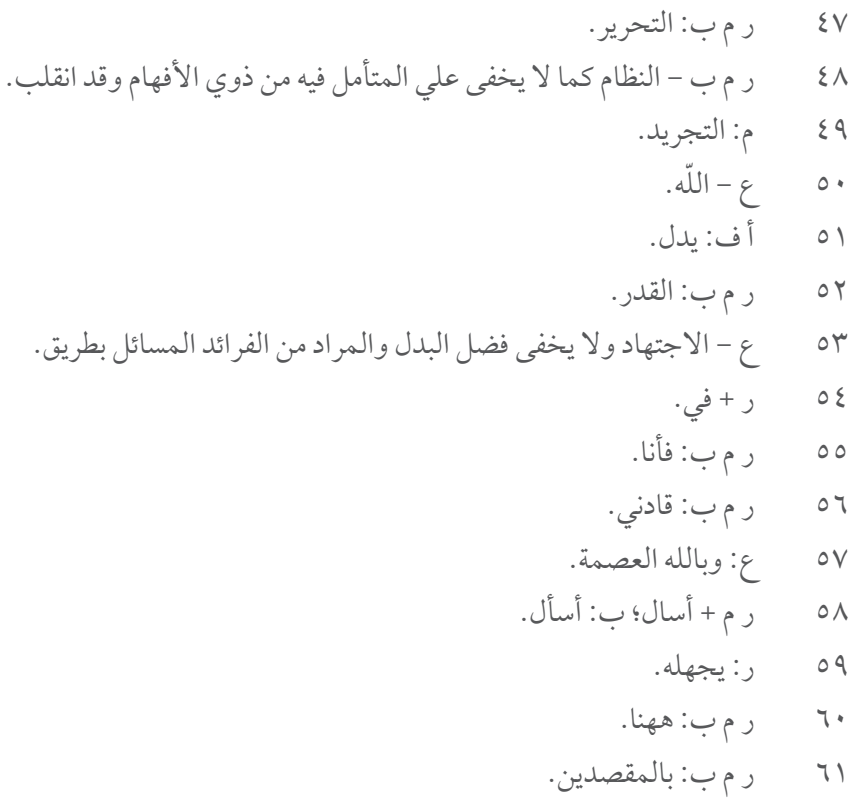




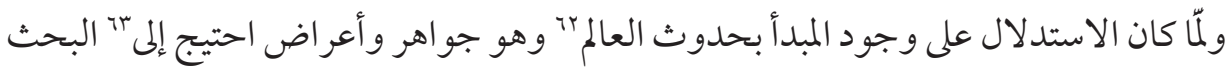

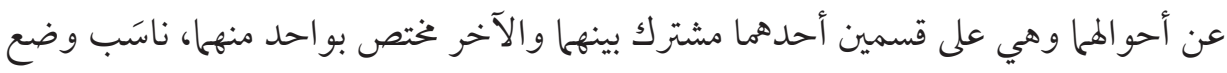

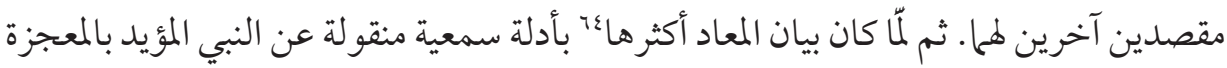

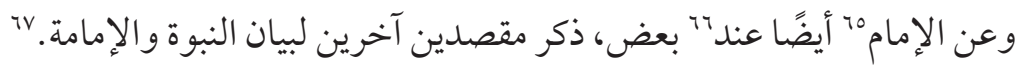

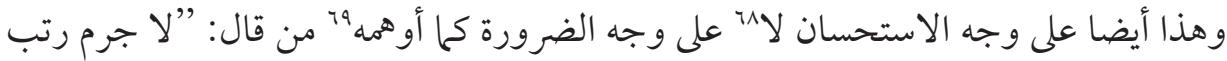

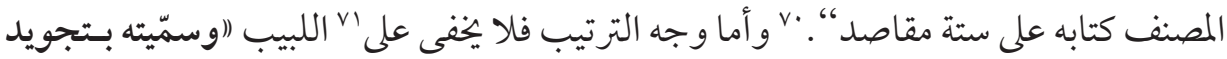

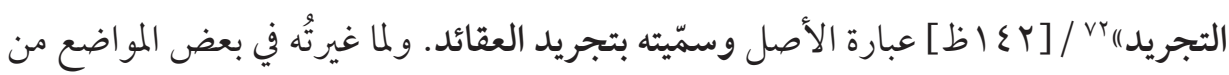

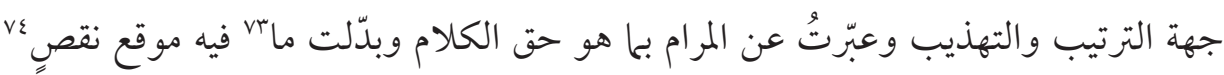

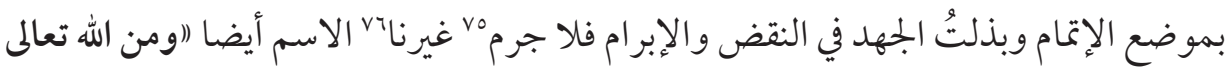

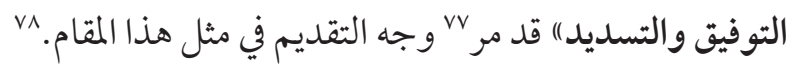

$$
\begin{aligned}
& \text { r } \\
& \text { צו }
\end{aligned}
$$

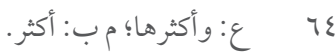

$$
\begin{aligned}
& \text { 10 } \\
& \text { 7و }
\end{aligned}
$$

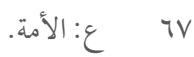

$$
\begin{aligned}
& \text { ش } \\
& \text { 79 } 79
\end{aligned}
$$

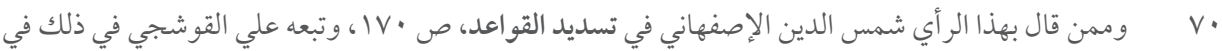

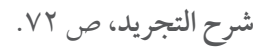

$$
\begin{aligned}
& \text { VI }
\end{aligned}
$$

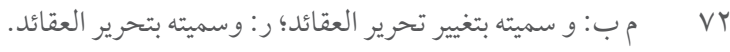$$
\text { رo }
$$$$
\text { رم رم: رم: }
$$

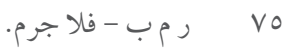$$
\text { VT }
$$$$
\text { رمب: VV VV }
$$

VA 


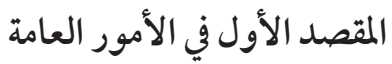

التعريف في الأمور للعهد، و المعهود المناسب للمقام ما لا دخول له في قسم من أقسام المو جود من

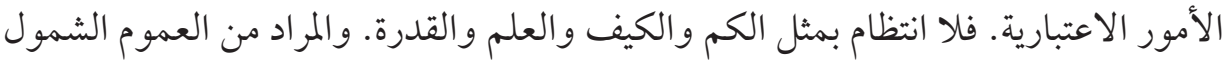

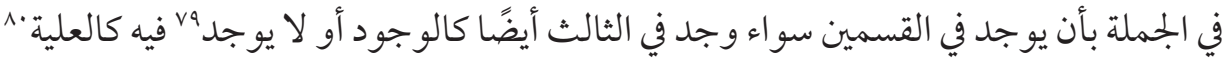

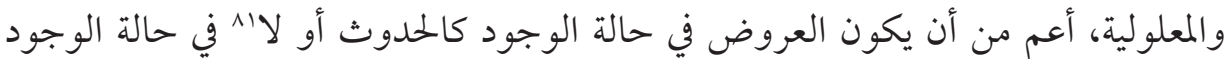

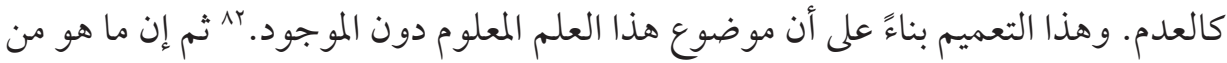

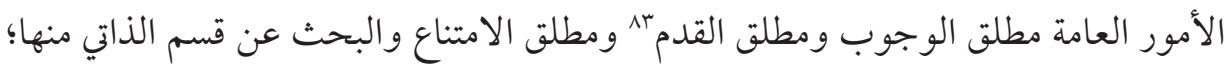
لأنه من أقسامها كالبحث عن الوجود الخاص الو اجبي و الماهية المجردة و العلة الفاعلية.

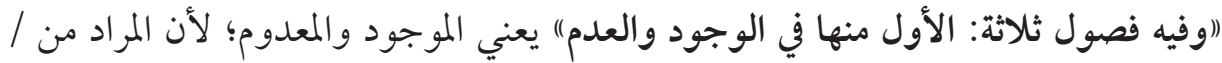

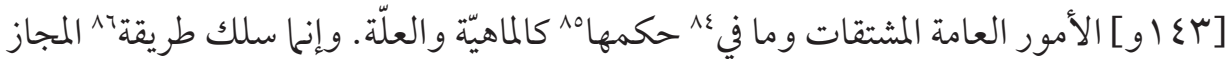

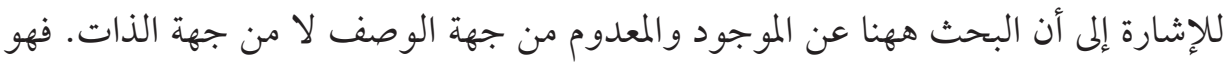

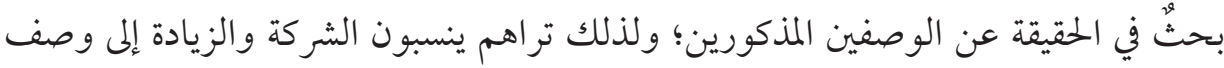
الوجود دون مفهوم الموجود.

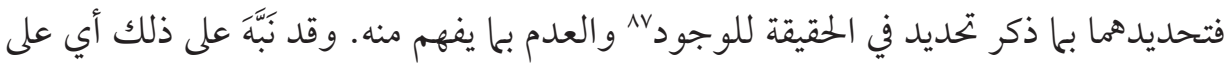

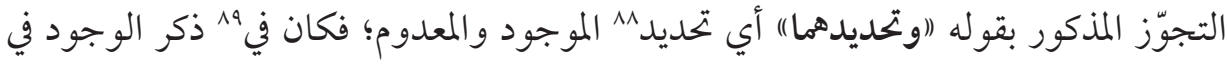

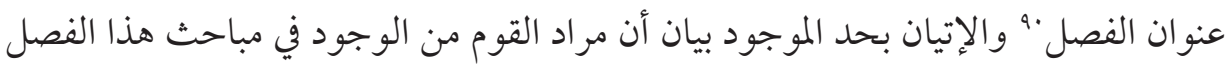

$$
\begin{aligned}
& \text { ع - في القسمين سواء وجد في الثالث أيضا كالو جود أو لا يو جد. }
\end{aligned}
$$

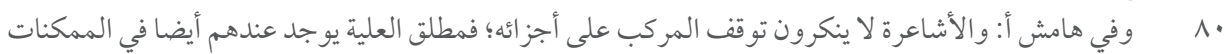

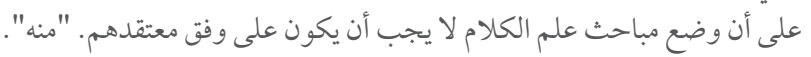

$$
\begin{aligned}
& \text { ع } 11
\end{aligned}
$$

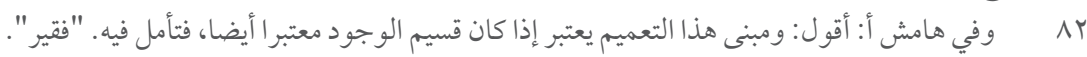

$$
\begin{aligned}
& \text { ( } \\
& \text { أ } 1 \text { أ في. }
\end{aligned}
$$

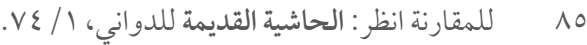

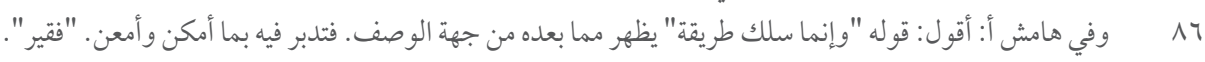

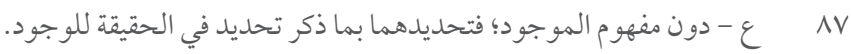

$$
\begin{aligned}
& \text { م ع: } \\
& \text { م } 19
\end{aligned}
$$

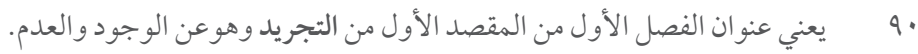




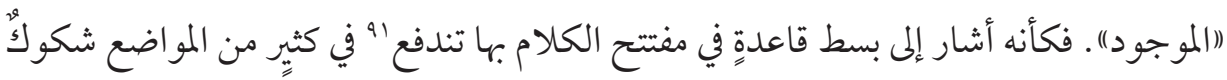

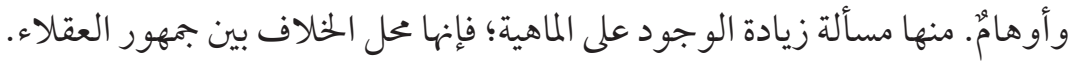

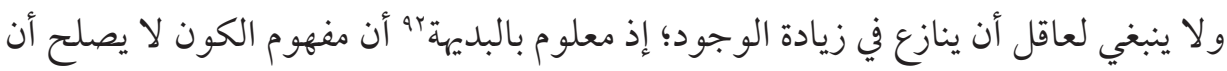
يكون عين الذات الخارجي. نعم يمكن أن ينازع في زيادة مفهوم الموجود و ومعنى الكائن.

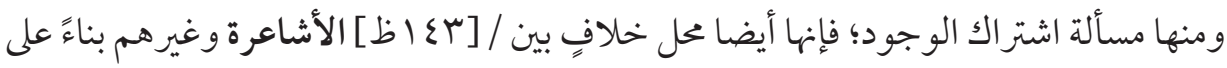

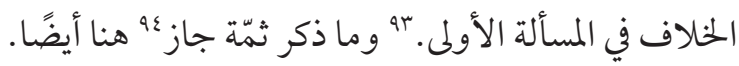

ومنها ما قالو ا: إن الوجود مقولٌ بالتشكيك بناءً على التفاوت في تحققه ف9 في ضمن أفر اده وذلك

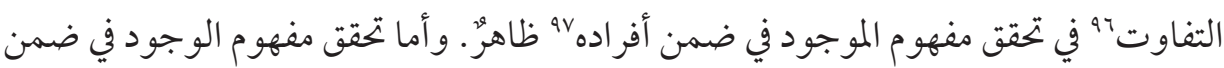

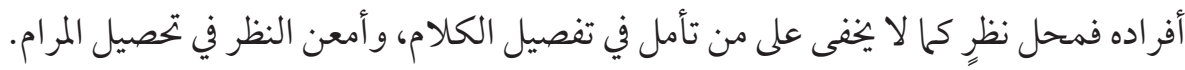
(بالثابت العين والمنفي العين) التقييد بـ)العين") للاحتراز عن الثابت للغير كالعمى الثابت في

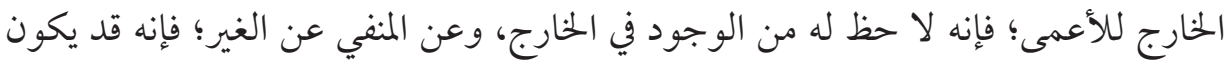

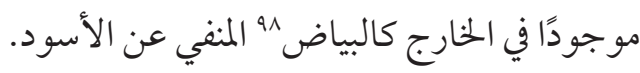
(أو الذي يمكن أن يخبر عنه) لا يتو همن صدق هذا الحد على المعدوم المطلق وهو معدومٌ مطلق؛ في

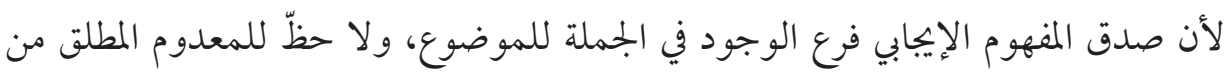

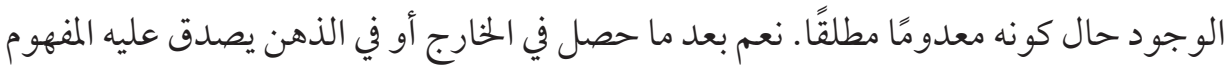

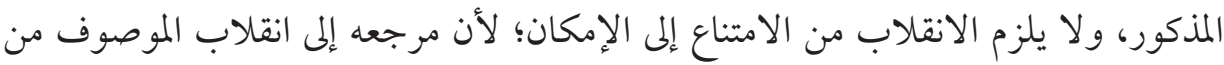

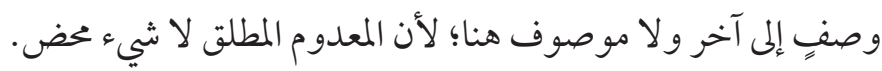

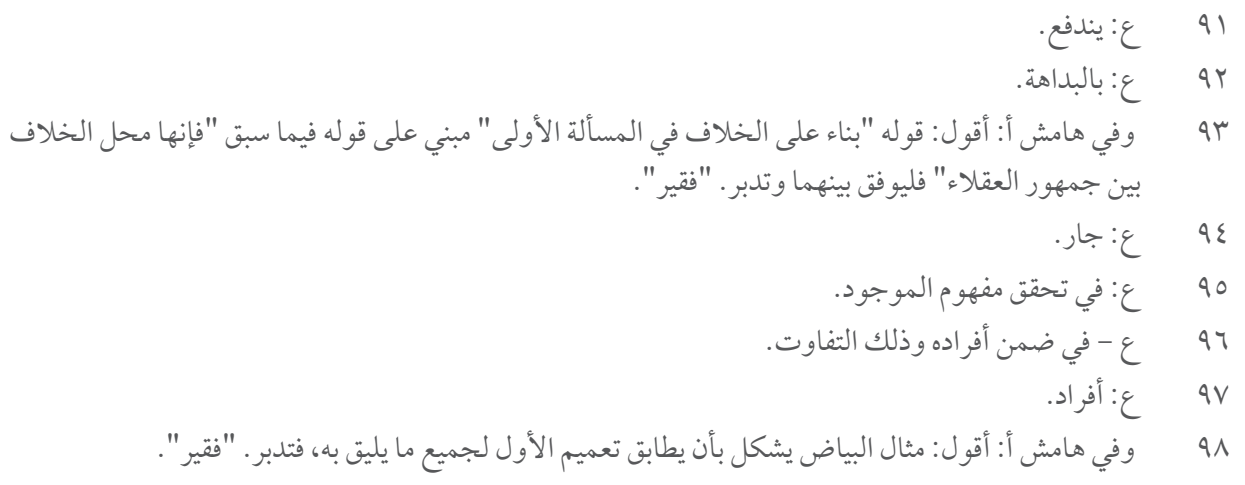




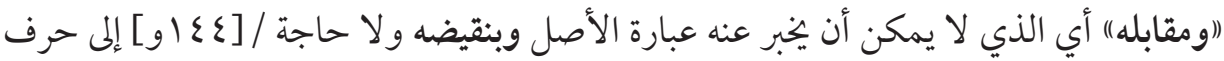

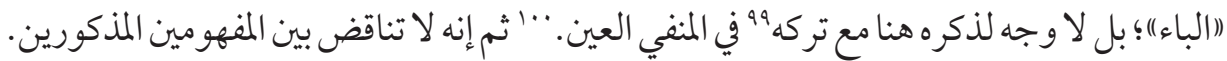

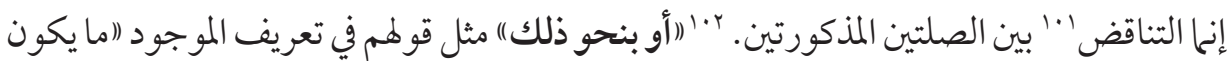

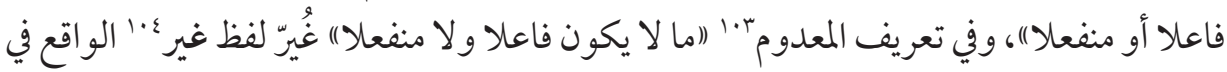

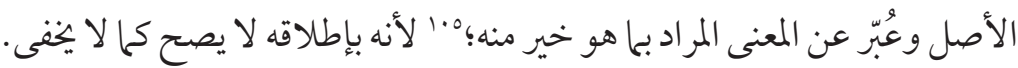
"يشتمل على دور ظاهر " لمج"1 يقل "(وفي تحديدهما دور ظاهر ") مع أنه أخصر و أظهر قصدًا بعبارة

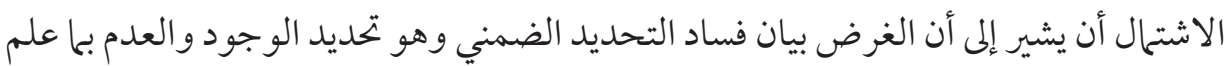

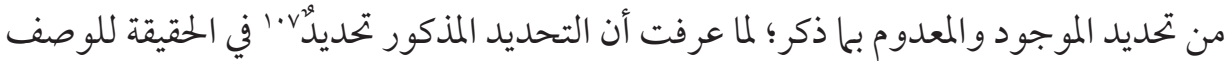

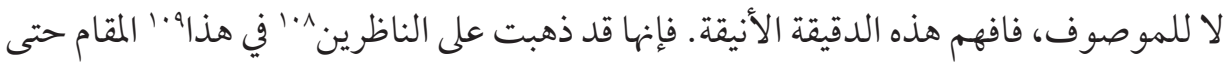

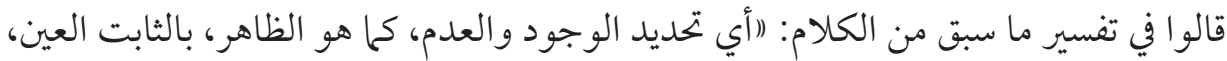

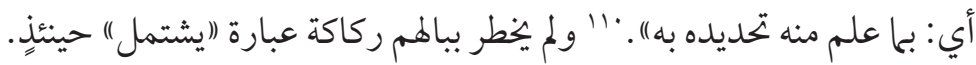

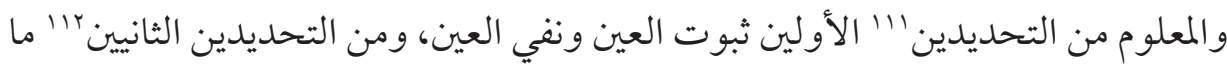

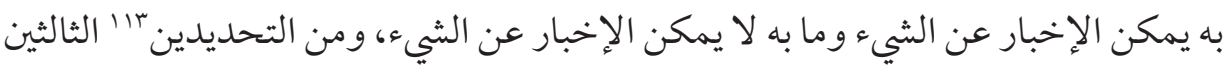

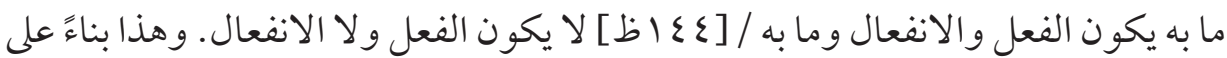

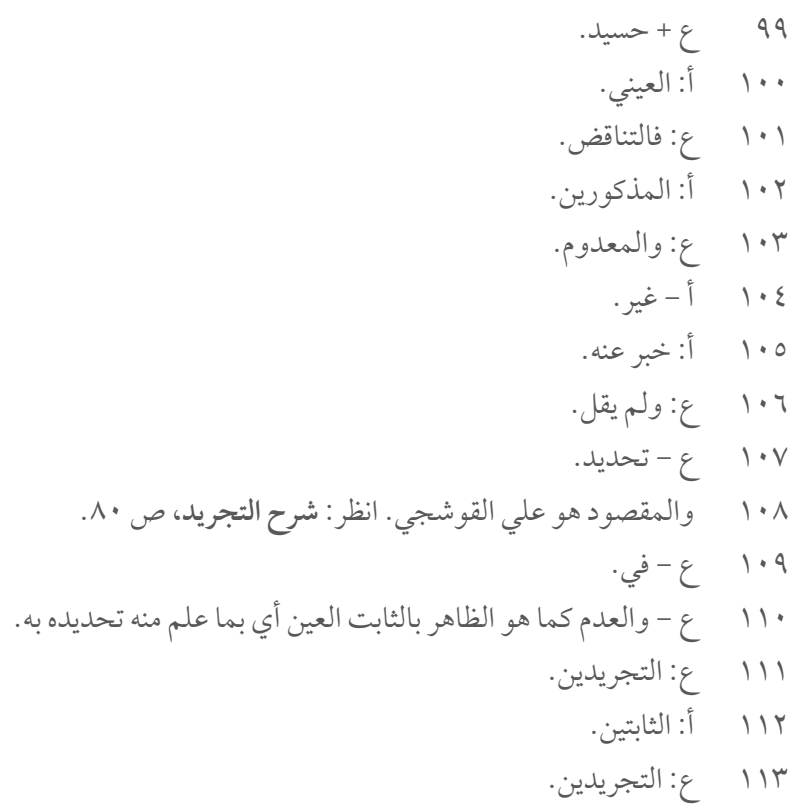


أن المقصود من تحديد الموجود و المعدوم تحديد مفهومها؛" "لا تحديد ما صدقا عليه؛ لأنها

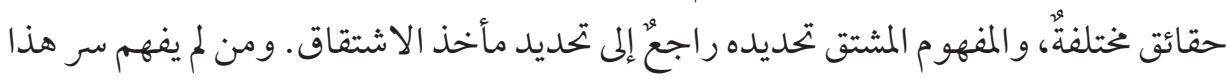

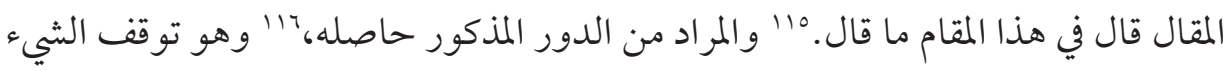

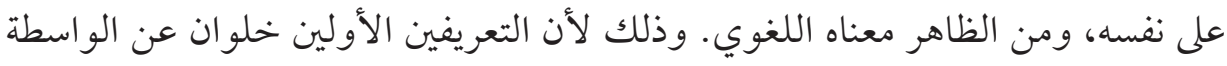

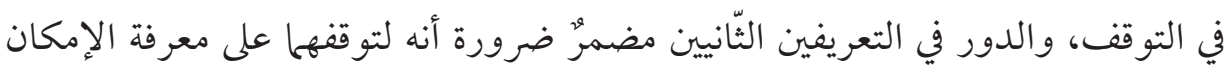

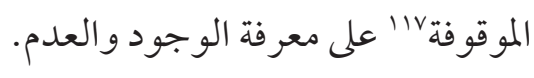

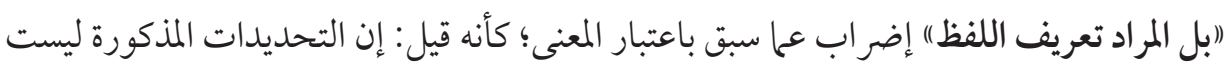

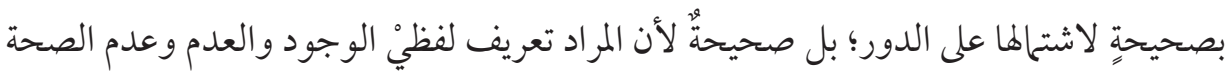

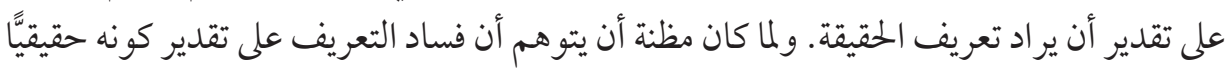

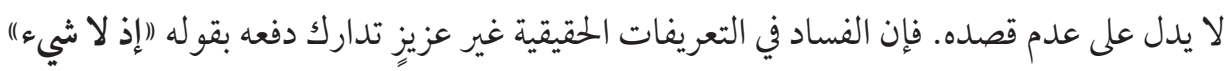

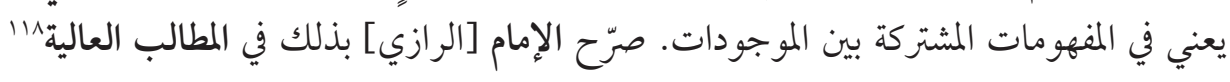

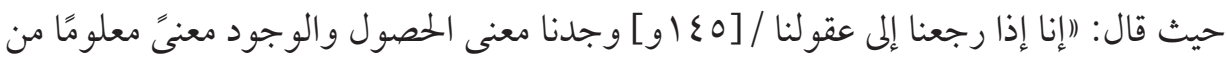

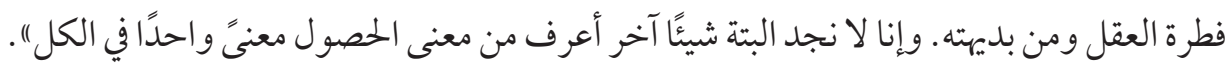
"(أعرَف من الوجود)" عندهم. فكيف تيسر "ا" لهم قصد تعريفه حقيقةً وهم يعرفون أن المعرِّف شرطه

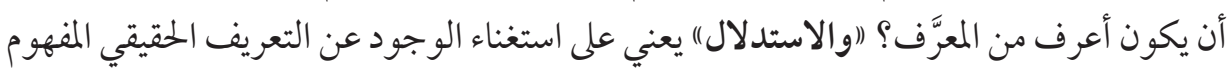

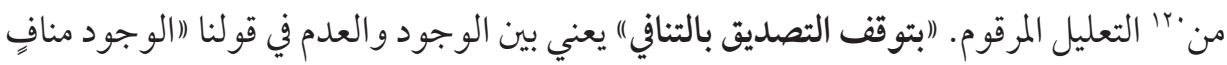

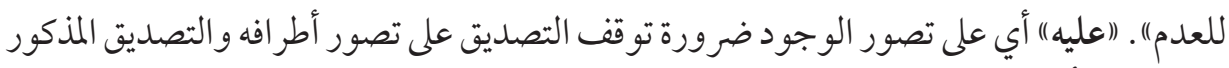

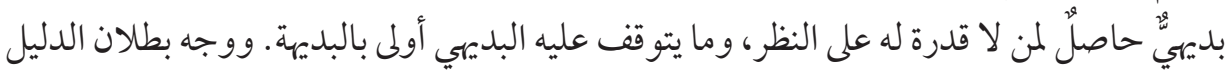

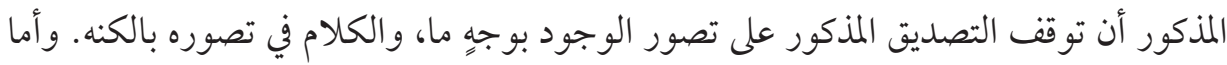

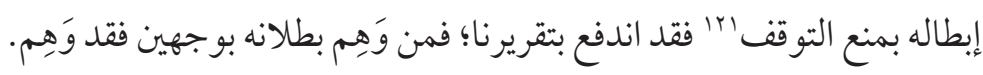

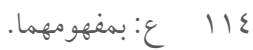

$$
\begin{aligned}
& \text { 110 } 110 \\
& \text { أ: أنطاصلة. } \\
& \text { IIV }
\end{aligned}
$$

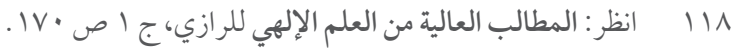

$$
\begin{aligned}
& \text { 119 }
\end{aligned}
$$

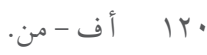

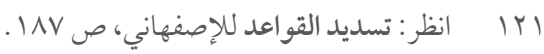


"(وبعدم قبول التحديد للزوم توقف الثيء على نفسه أو خلاف المفروض)" عبارة الأصل وبتوقف

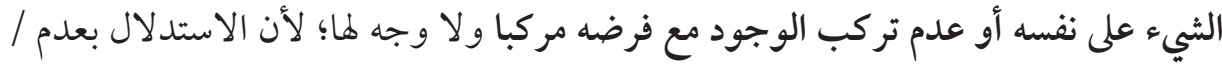

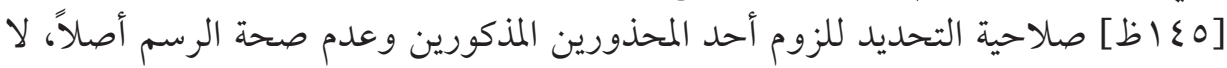

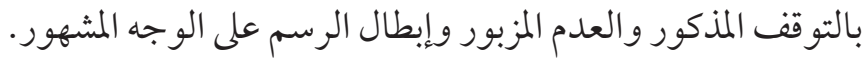

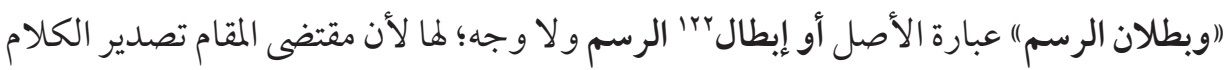

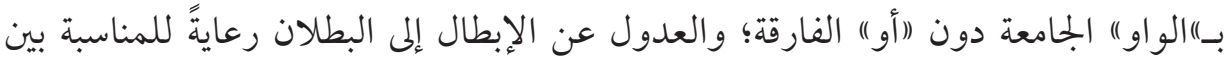

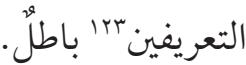

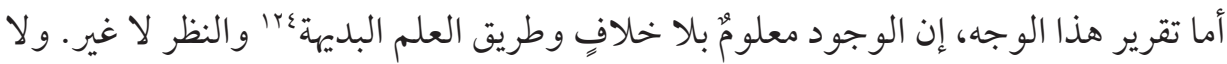

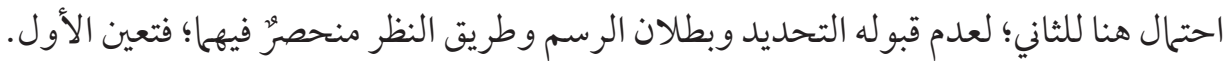

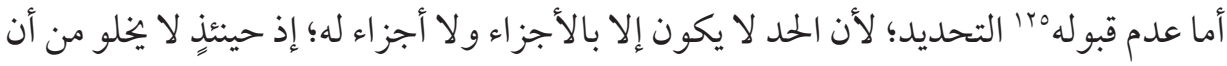

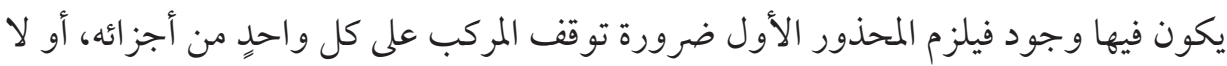

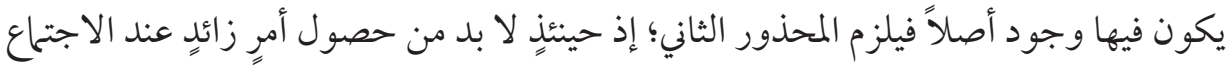

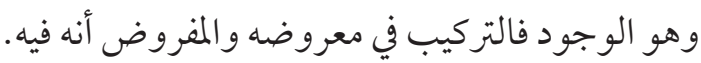

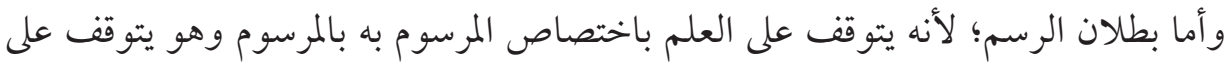

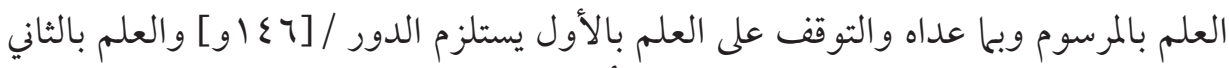

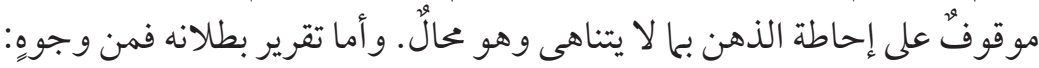

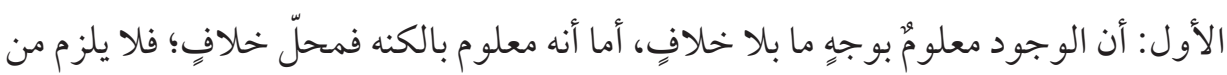

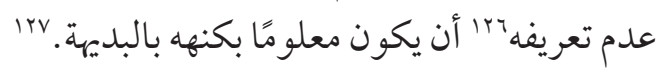
والثاني: أنا نختار أن في أجزائه وجودًا، ونمنع لزوم الفساد؛ فإن الجزء كالحيوان يصدق على

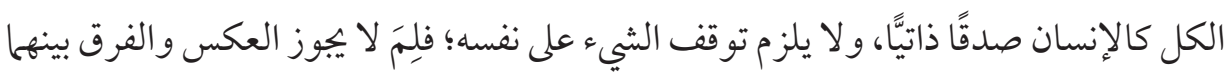


بالصحة و الفساد دون خرط القتاد؟ وأما الجو اب بـ“"أن الوجود عرضي لجزئه بُ لا ذاتي؛ فاللازم

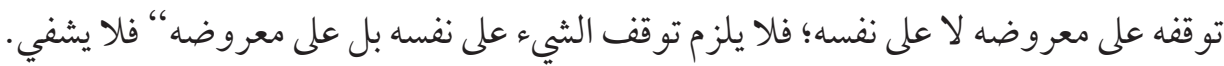

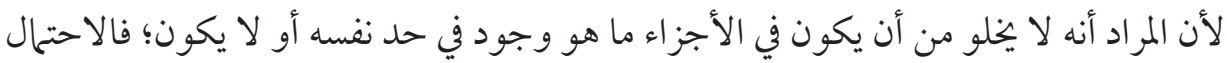

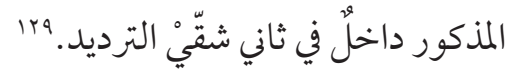

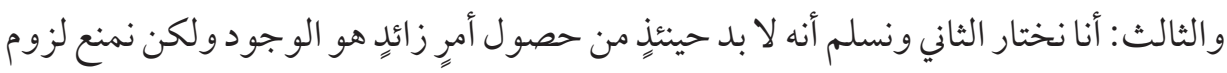

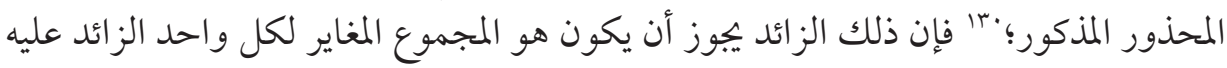

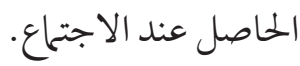

و الرابع: النقض بالمركبات التي لا خلاف في تركيبها حقيقة؛ فإن الدليل المذكور على تقدير تمامه يدل على ان لا يو جد مركب أصلاًا. والخامس أن التوقف / [حـ اظ] في الرسم على نفس الاختصاص لا على العلم به، والمحذور المذكور

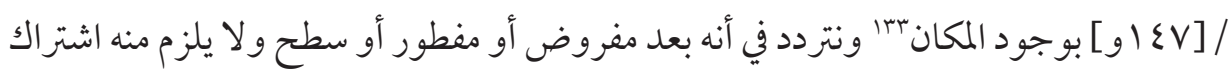
مفهوم المكان بين الثلاثة المذكورة في نفس الأمر.

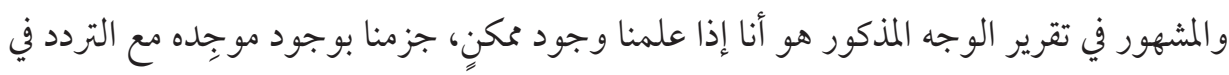

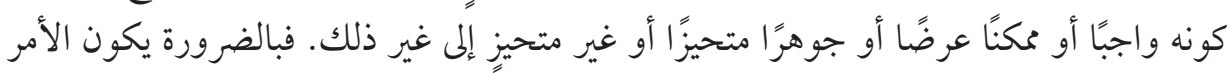

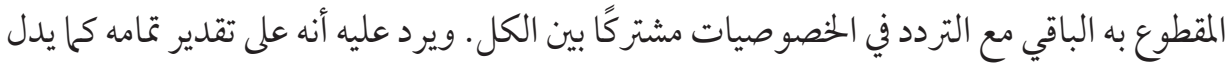

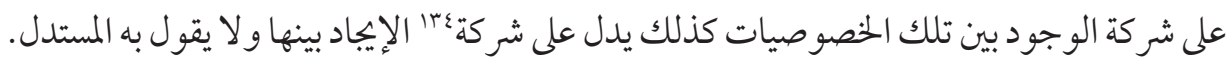
و الثاني منها: ما ذكره بقوله (اواتحاد مفهوم العدم)". وتقريره: أن العدم مفهومٌ و احدّ؛؛ إذ لا تمايز

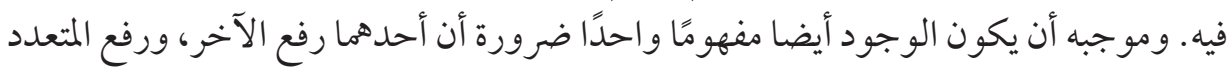

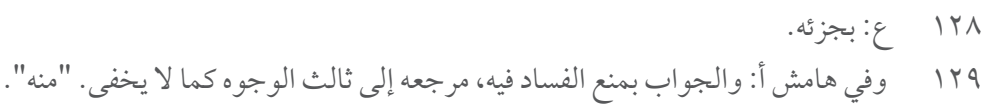

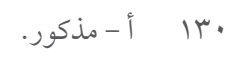

$$
\begin{aligned}
& \text { اسب آر ع- المذكور. }
\end{aligned}
$$

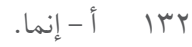

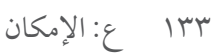

$$
\begin{aligned}
& \text { ع سا أ: اشتراك. }
\end{aligned}
$$




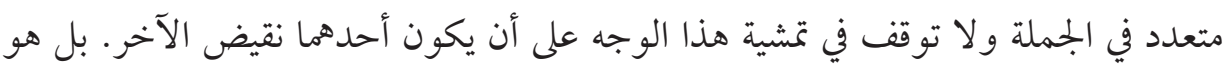

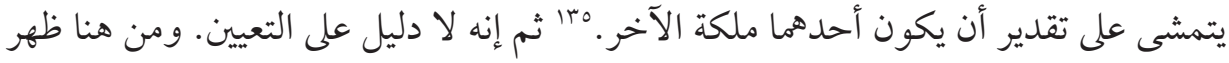
وجه الإصابة في العدول عن عبارة النقيض الو اقعة في الأصل.

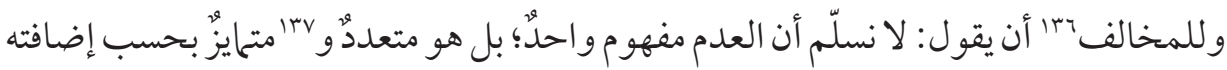

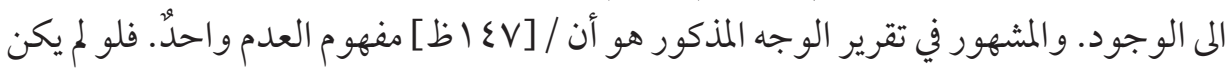

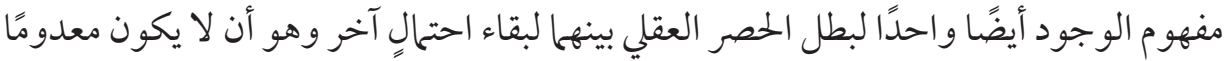

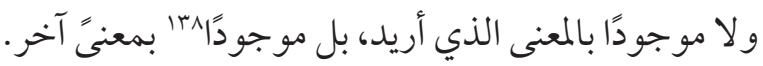

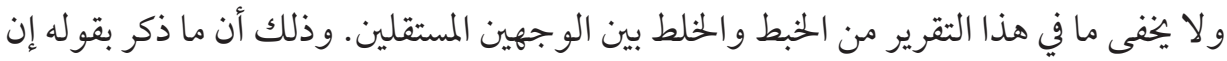

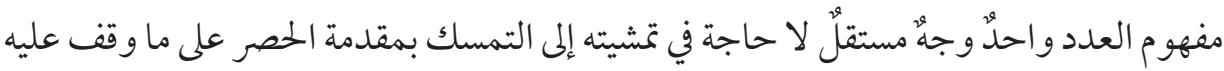

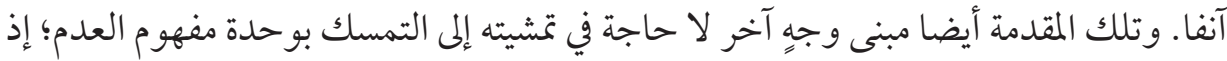
على تقدير تعدده يكون بطلان الخصر أظهر.

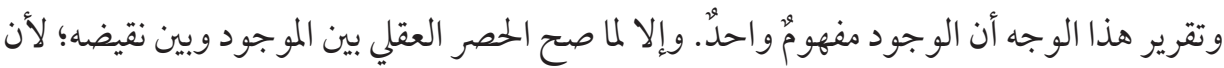

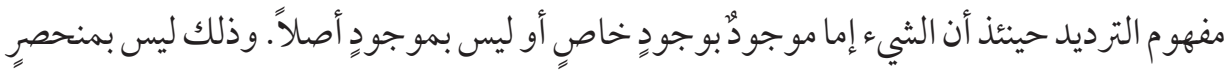

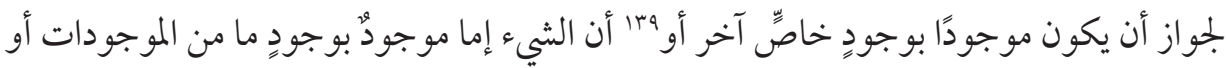

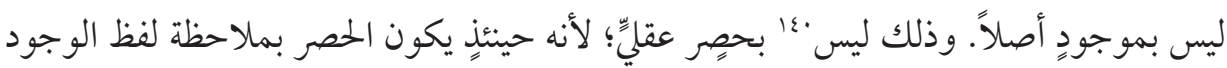
وشموله تلك المعاني المتعددة التي وضع بإزائها؛ فلا يكون عقليًّا معنويَّا بل استقر ائَّا لفظيَّا. لا يقال: (الا بد في تمام هذا الوجه من بيان وحدة مفهوم العدم؛ إذ على تقديرها يكون معنى

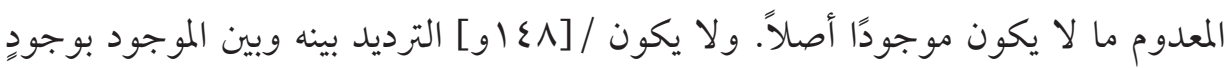

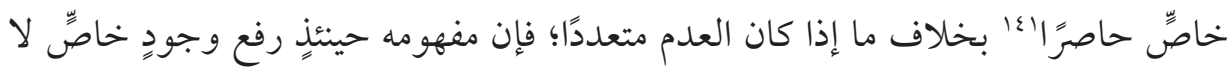

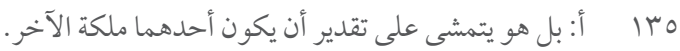

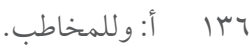

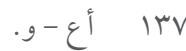

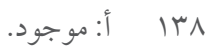

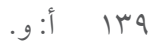
•

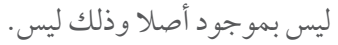


رفع الوجودات بأسرها؛ فيكون الترديد بينه وبين ذلك الوجود حاصرًا من غير ملاحظة المقدمة

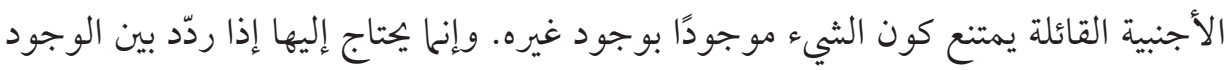
الخاص ورفع الوجودات بأسرها) .

لأنا نقول: الحصر الذي تمسك به في تقرير الوجه المذكور، الخصر بين الموجود والمعدوم بمعنى

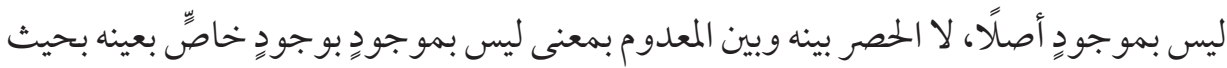

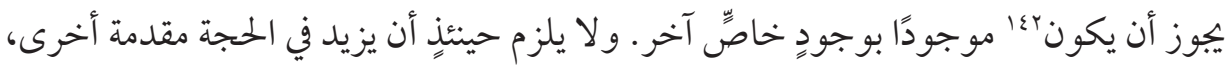

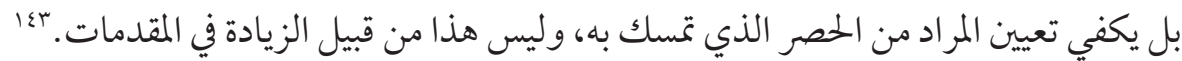
والثالث منهاء": ما ذكر بقوله (اوقبوله القسمة)، وتقريره: أن الوجود يقبل القسمة إلى وجود

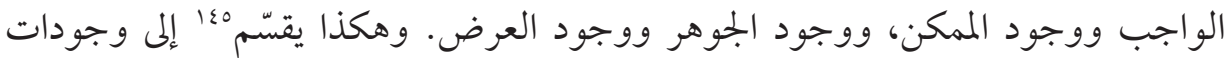

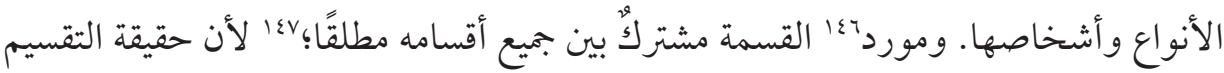

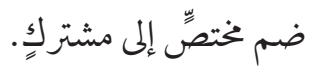

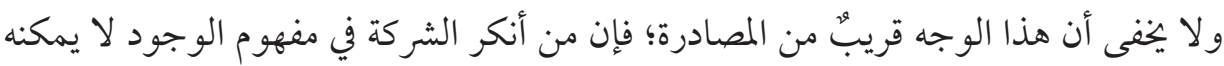

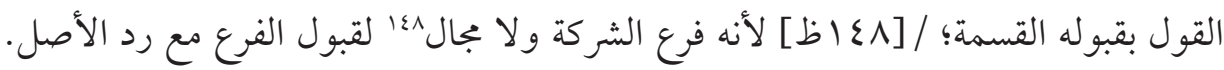

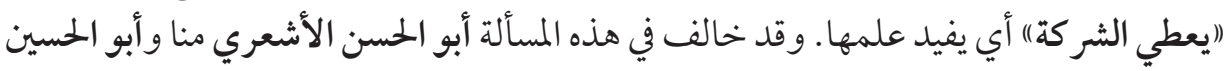

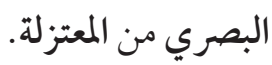

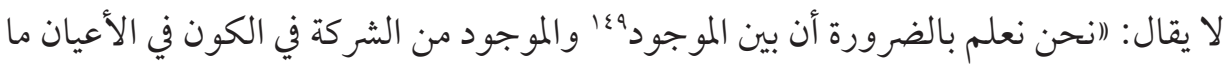

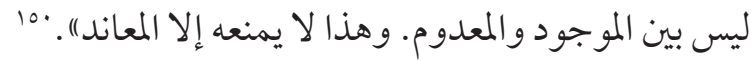

$$
\begin{aligned}
& \text { ع اع } \\
& \text { أ - أنها. } \\
& \text { إ: القسم. } \\
& \text { أ: بين }
\end{aligned}
$$

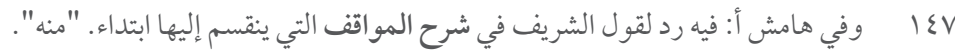

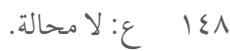

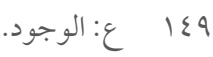

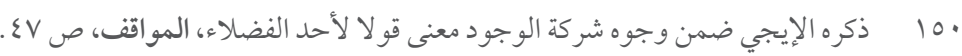


لأنا نقول: فيه تجهيلّ للفريقين؛ لأن من قال بالشركة تمسك فيه بالحجج ولقد أبدع من نظم دعوى

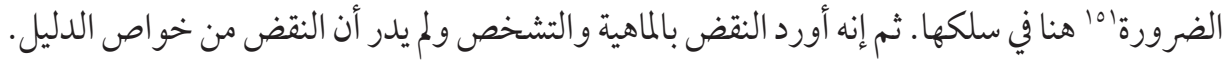
لا يقال: (لعل المخالف لا ينكر الشركة في معنى الكون). بل نقول: إن للوجود اor معنى آخر وراء الكون؛ لأنه حينئذِ يلزم أن لا يكون محل النّزاع محرًّا بين الفريقين.

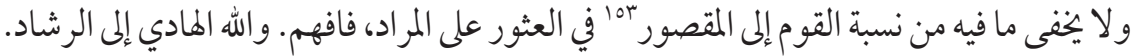

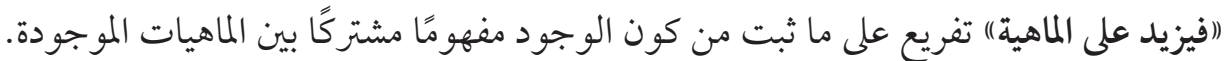

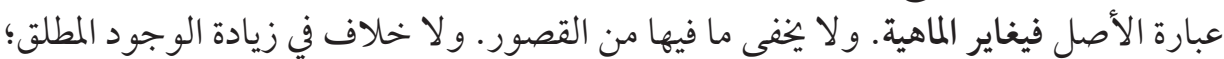

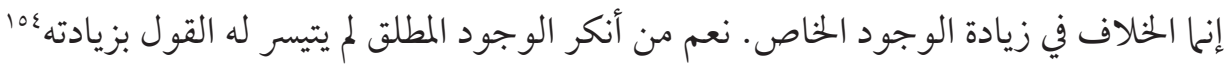

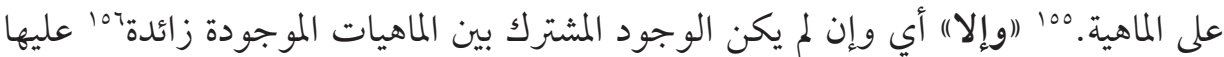

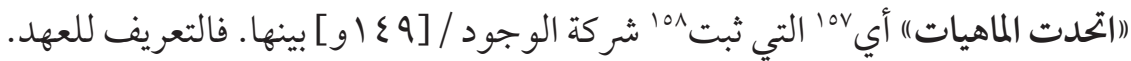
(أو كان) أي الوجود (جزءًا لنفسه)؛؛ لأنه 109 لا يخلو من أن يكون عينها، فيلزم المحذور الأول

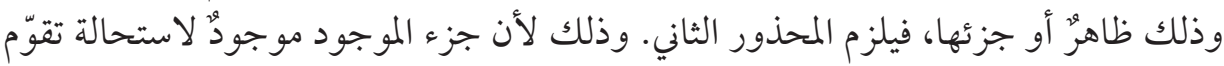

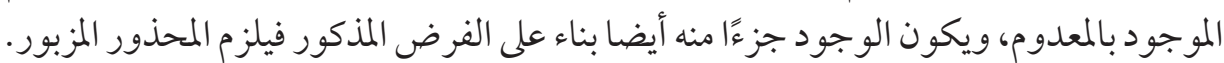

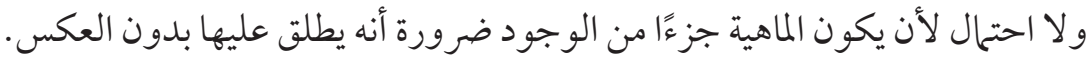

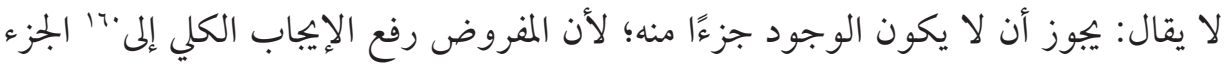

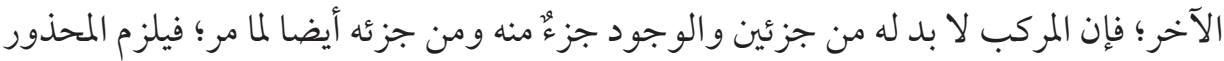

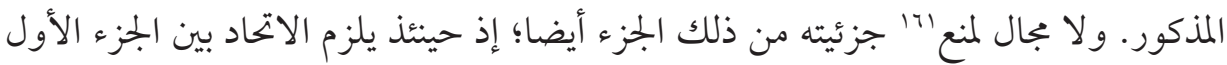

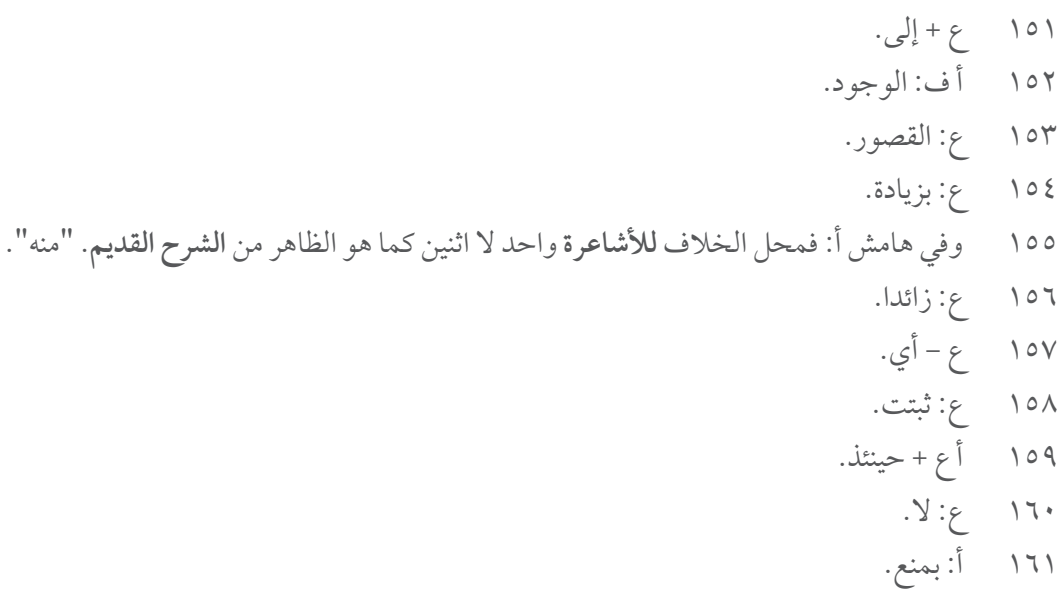


وجزء الجزء الثاني، وفساده ظاهر . ولا يتجه على هذا التقرير إلا أن يقال: يجوز أن يكون الوجود

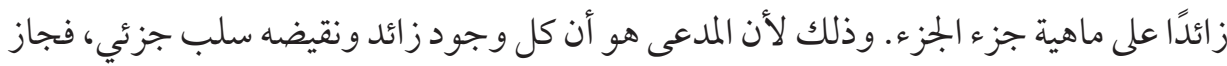

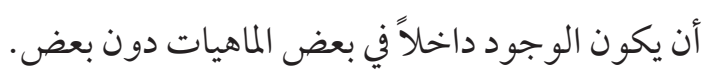

عبارة الأصل وإلا لم ينحصر أجزاؤها. وتقريره: أنه لو كان الوجود جزءًا للماهيات لكان لها لهان

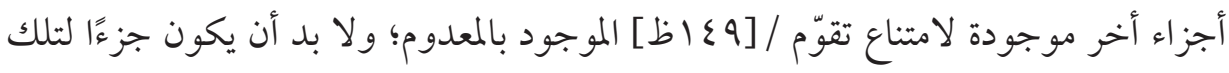

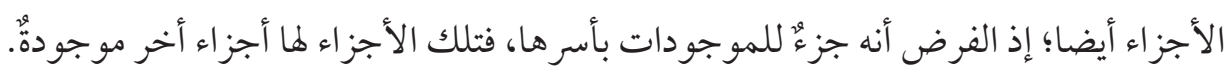

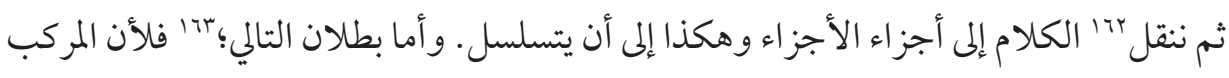

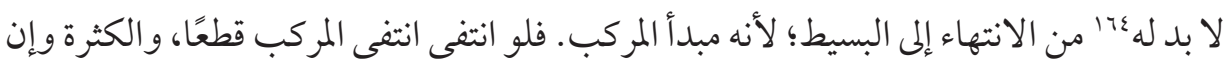

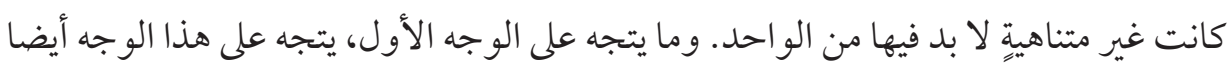

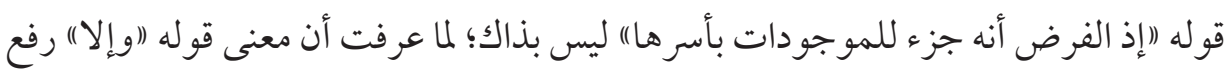

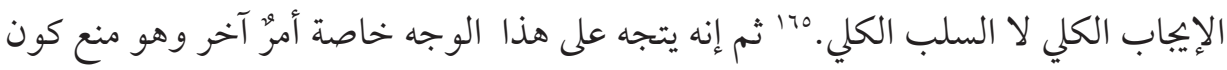

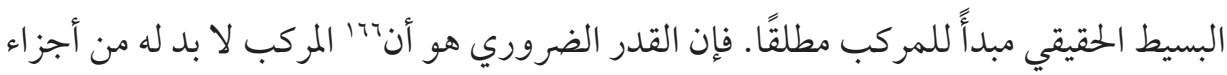

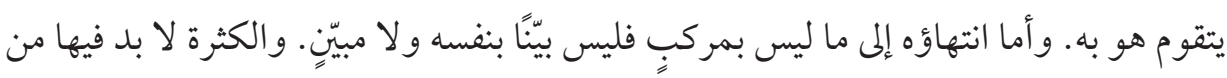

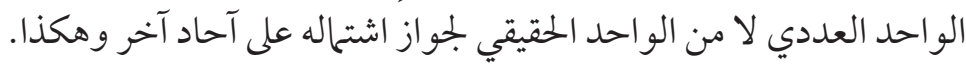

فإن قيل: أليس يكفي في بطلان التالي أن يقال (او التسلسل باطل)؛

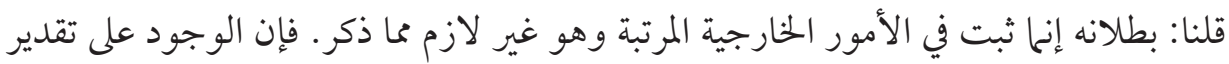

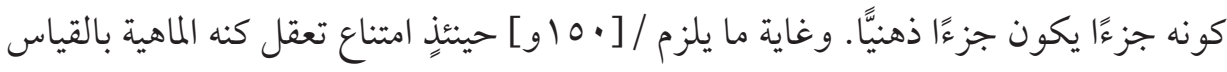

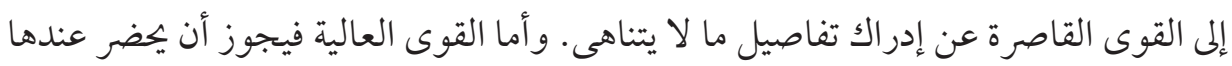

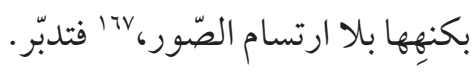

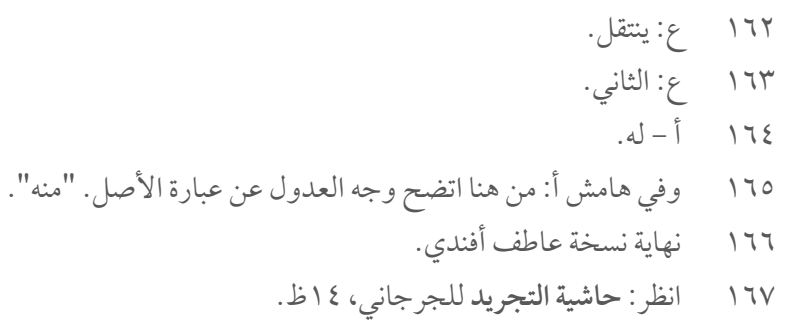


"ولانفكاكها)" أي ولانفكاك كل من الوجود و الماهية عن الآخر "(تعقّلا) عطف على ما تقدم

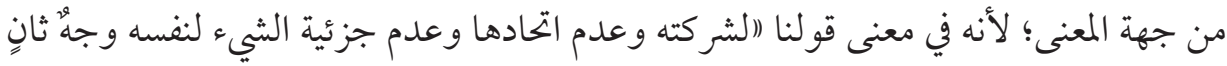

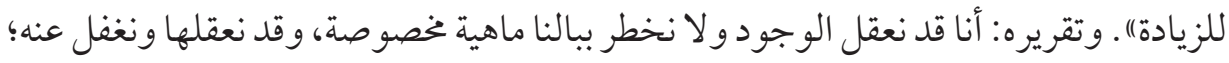
وهذا لا يتصور بين الشيء وذاتيه.

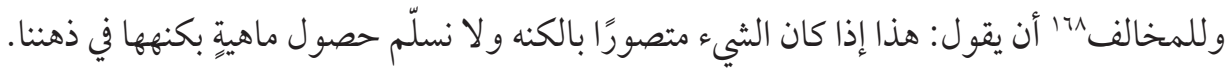

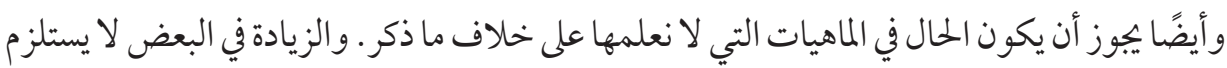

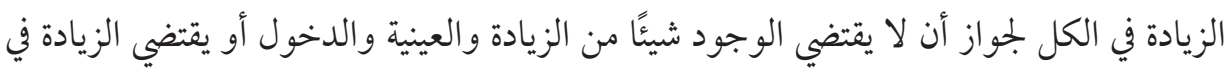

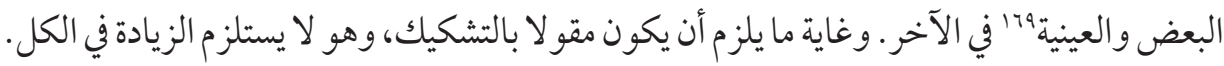

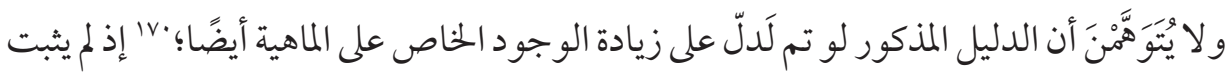

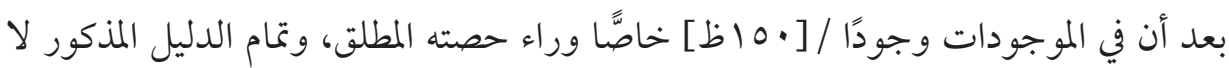

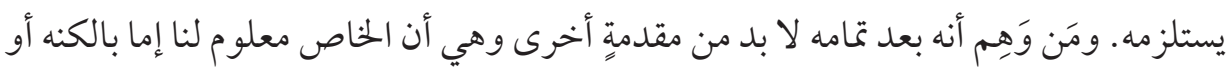

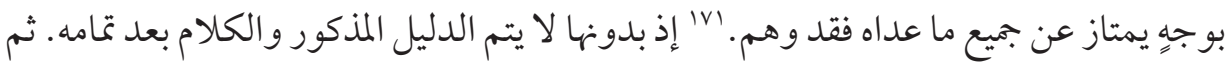

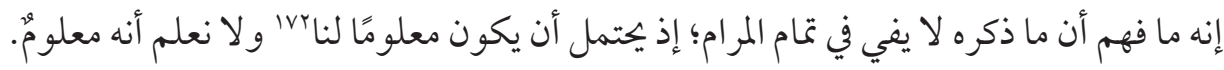

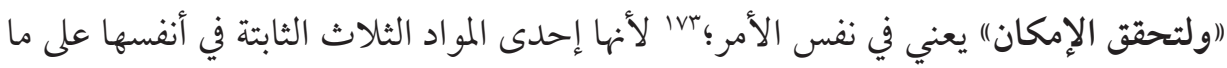

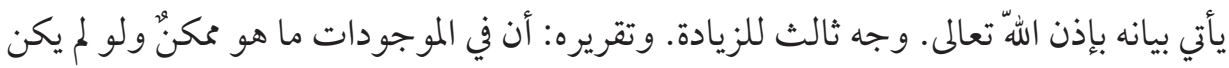

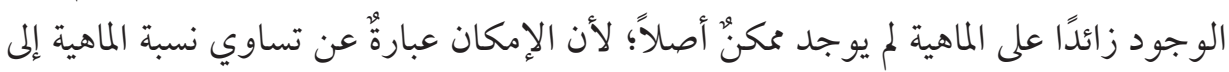

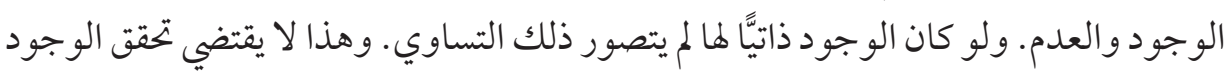

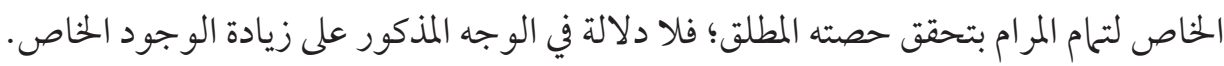

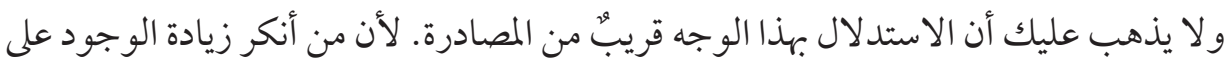

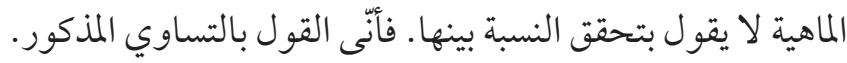

\footnotetext{
171 أ: وللمخاطب.

179

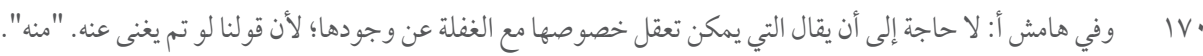

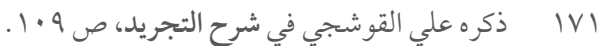

IVY

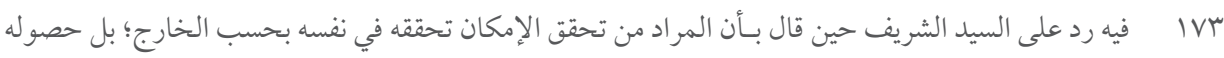

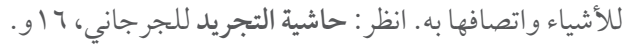




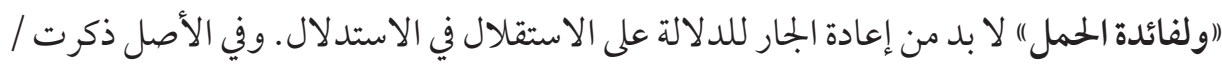

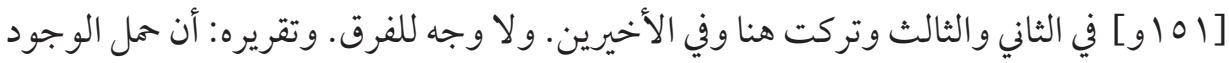

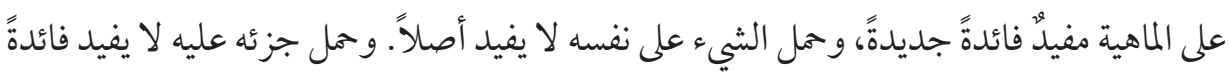

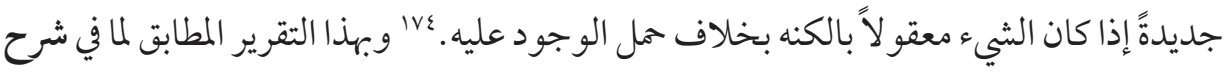

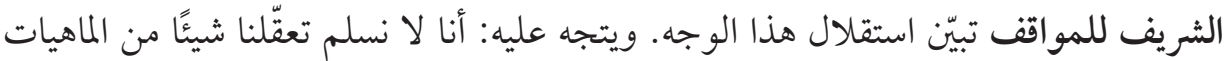

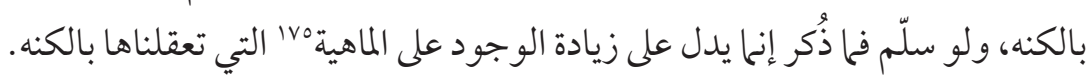

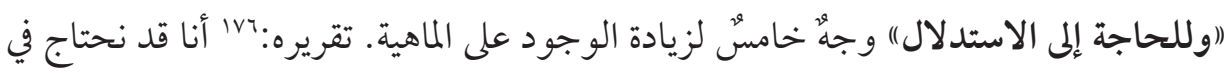

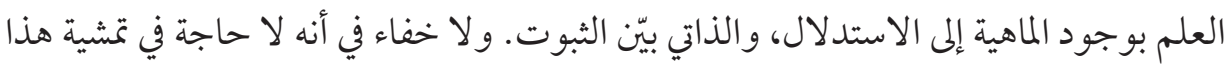

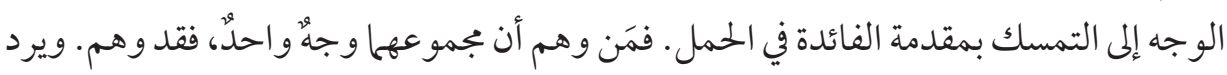

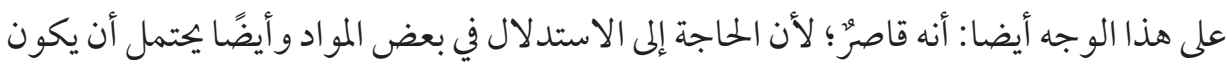
ذلك لعدم تعقلّها بالكنه.

"ولانتفاء التناقض وتركب الواجب" عطف على المضاف إليه أي لانتفاء هذين الأمرين.

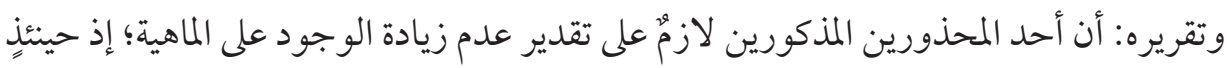

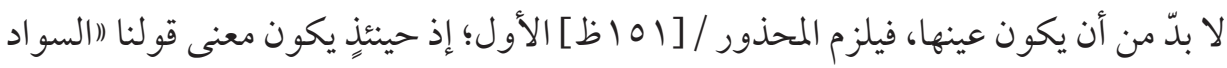

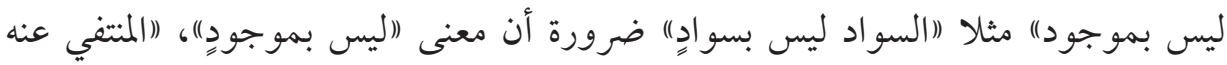

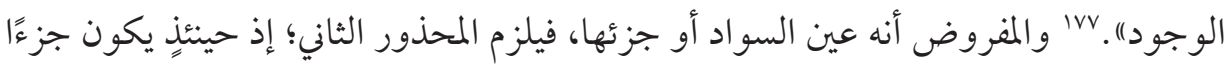

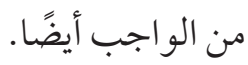

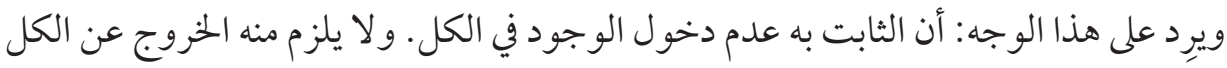

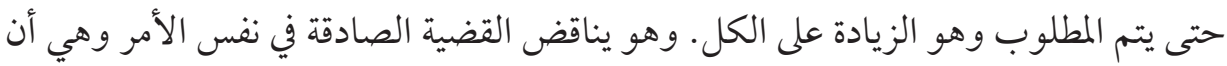

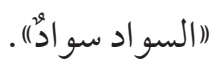

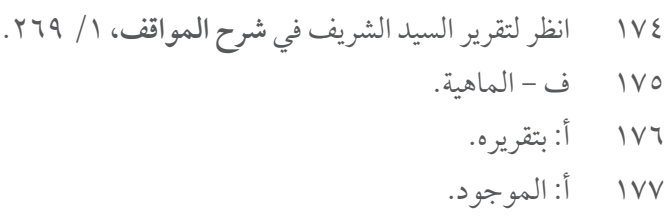


تَجْرِيدُ الإعِتِقَادِ للطُوِِي

أَمَّا بَعَدَ حَمْدِ وَاجِبِ الوُجُودِ عَلى نَعْمَائِه،

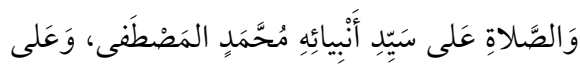

أَكْرَمْ أَحِبَّائهِ..

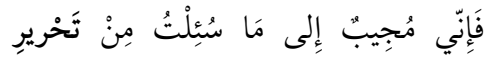

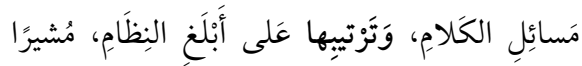

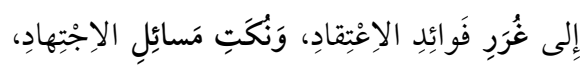
مِمّا قَادني الدَّلَّلُ إِلَيْهِ، وَقَوِي اعْتِمادي عَلَيْهِ.

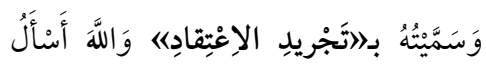
العِصْمَةَ وَالسَّدادَ، وَأَنْ يَجْعَلَهُ ذُخْرُا لِيْْوْم المَعادِ.

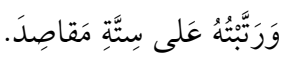

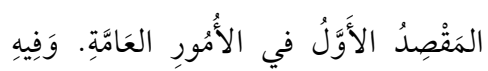

فُصُولْ ثَكَاثَةُ.

الفَصْلُ الأَوَّلُ في الوُجُودِ وَالعَدَمِ.

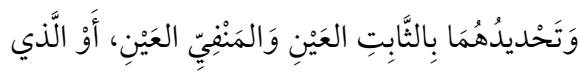

يُمْكِنُ أَنْ يُخْبَرَ عَنْهُ وَنَقِيِْهِ، أَوْ بَغَيْرِ ذَلَكَ، يَشْتَمِلُ

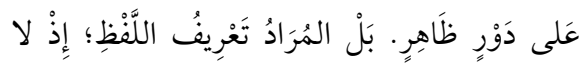

شَيْ أَعْرَفُ مِنْ الوُجُودِد.
تَجْويدُ التَّجْرِيدِ لِلْمَوْلى كَمَال بَاشَازَادَه

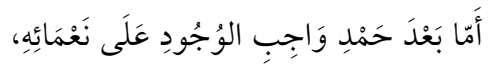

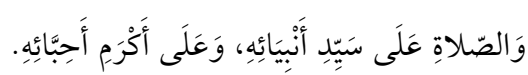

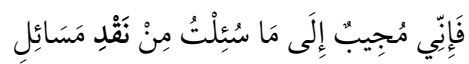

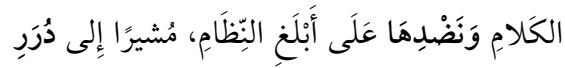

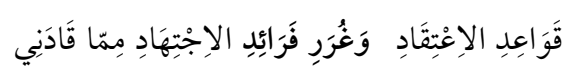

الدَّليلُ إِلَيْهِ، وَقَوِيَ اعْتِمَادي عَلَيْهِ.

وَاللّة أَسَأَلُ العِصْمَة وَالسَّدَادَ، وَأَنْ يَجْعَلَه

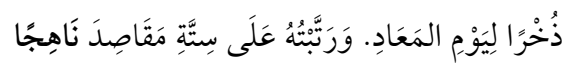

مَنْهَجَ المُنْهِفِ القَاصِدِ.

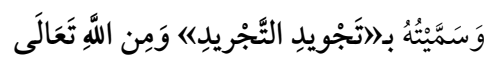

التَّوْفيقُ وَالتَّْدِيدُ.

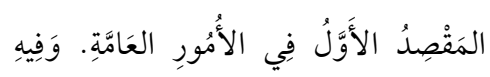

فُصُولْ ثَلَاثَةُ.

الأَوَلْ فِي الوُجُودِ وَالعَدَمْ. وَتَحْدِيدُهُمَا

بِالثَّابِتِ العَيْنِ وَالمَنْفِيَّ العَيْنِ، أَوْ الَّذِي يُمْكِنْ أَنْ يُخْبَرَ عَنْهُ وَمُقَابِلِهِ، أَوْ نَحْوِ ذَلِكَ، يَشْتَمِلُ عَلَى دَوْرِ

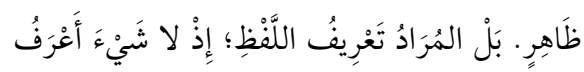
مِنْ الوُجُجودِ. 
The first and last folios of the manuscripts of Sharh al-Tajwìd

1) Bibliotheque nationale de France (Paris), AY, nr. 4374
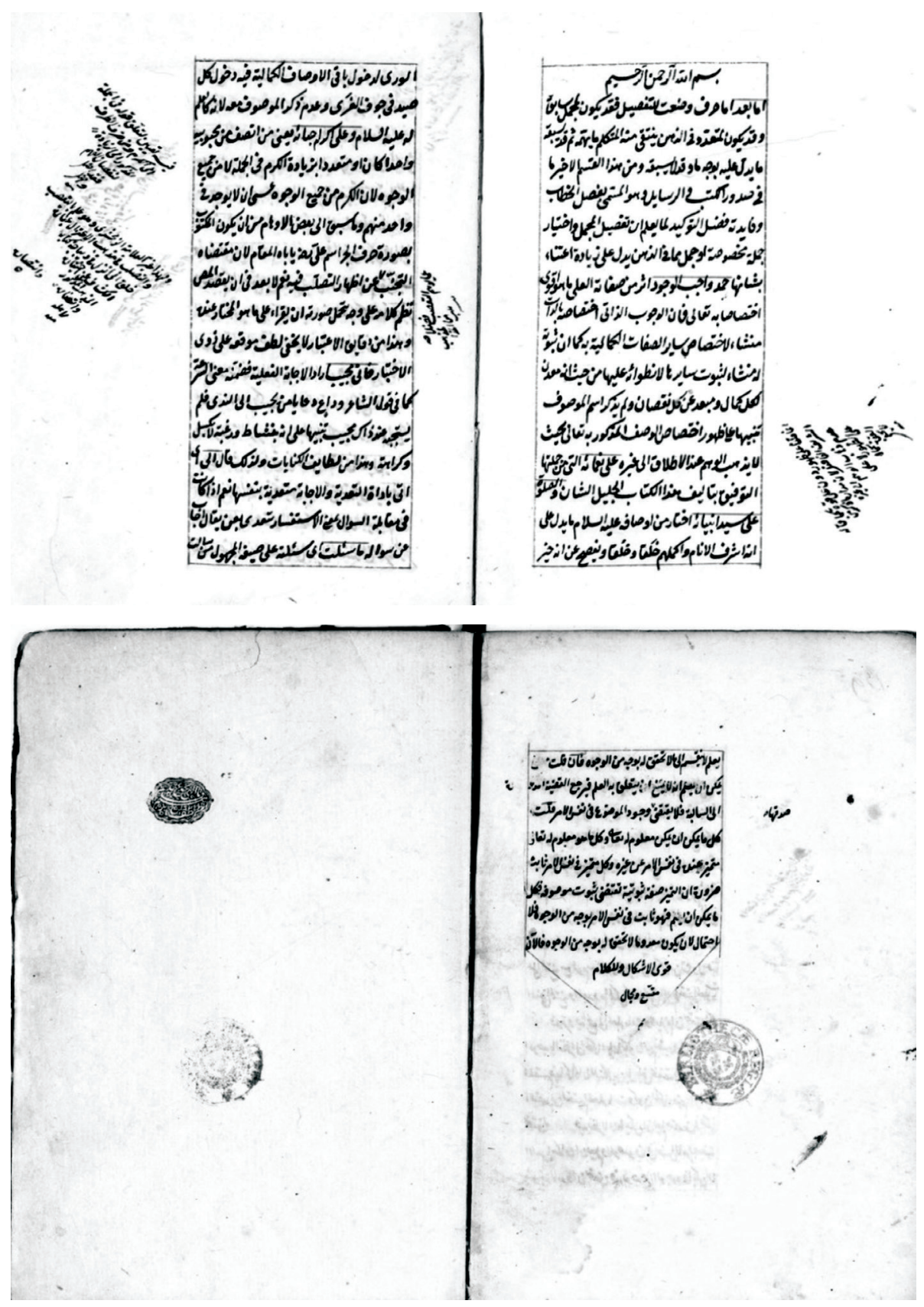
2) İnebey Manuscript Library,(Bursa), General, n. 4672.
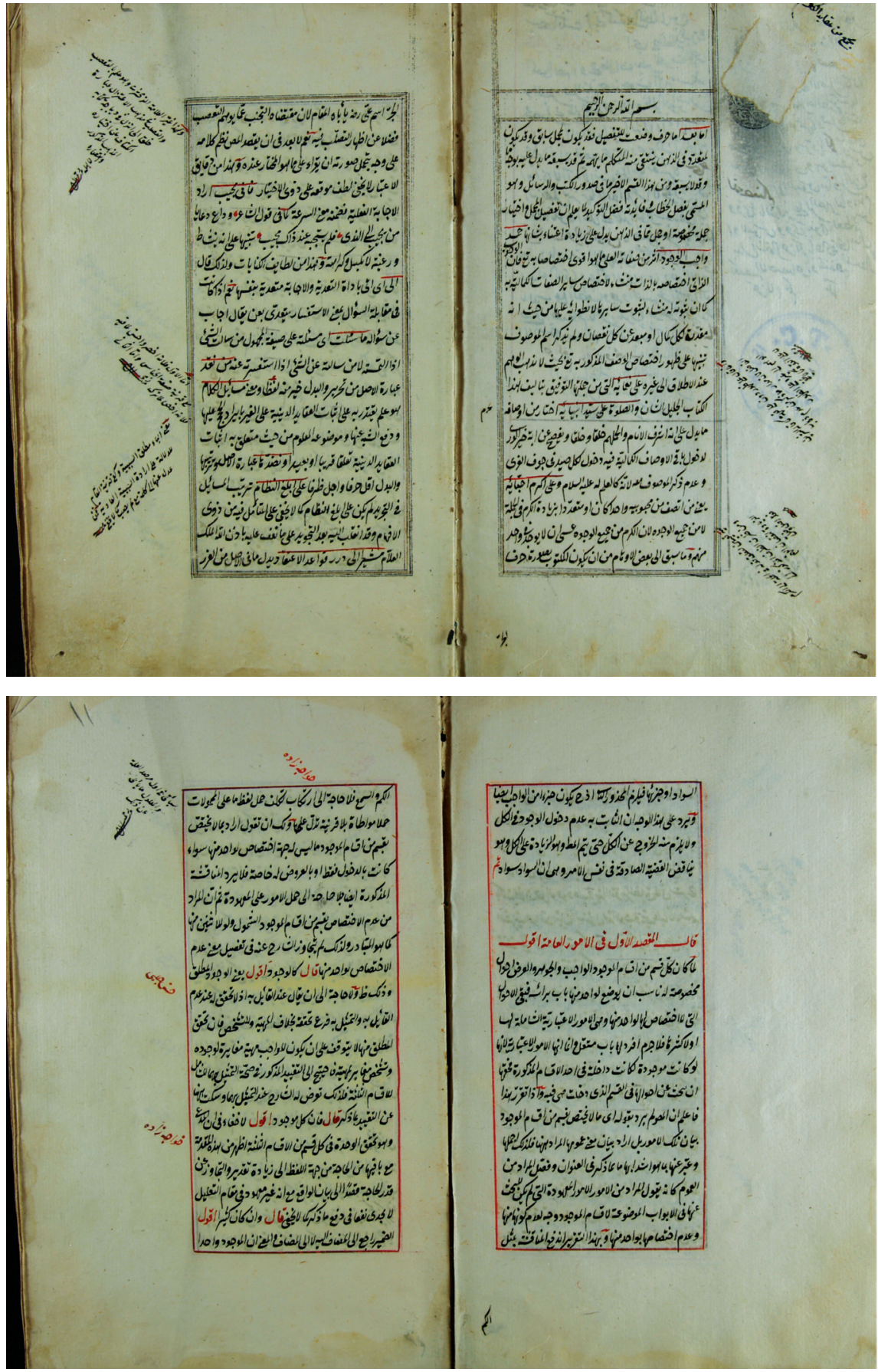
Ömer Mahir Alper, Yasin Apaydın, Tajwīd al-Tajrīd as Kemālpāshāzāde's Critique and Reconstruction of Tajrīd:

Study and Critical Edition

\section{3) Süleymaniye Library, Atıf Efendi, n. 2816}

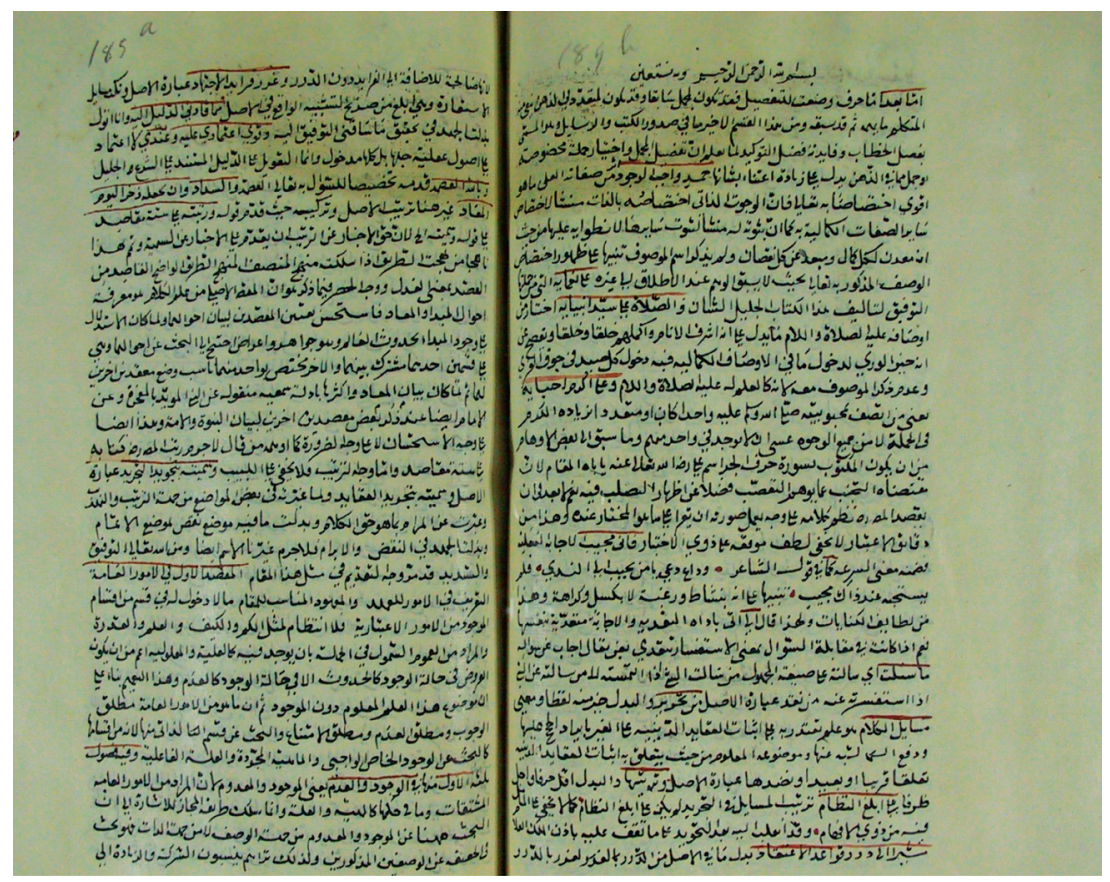

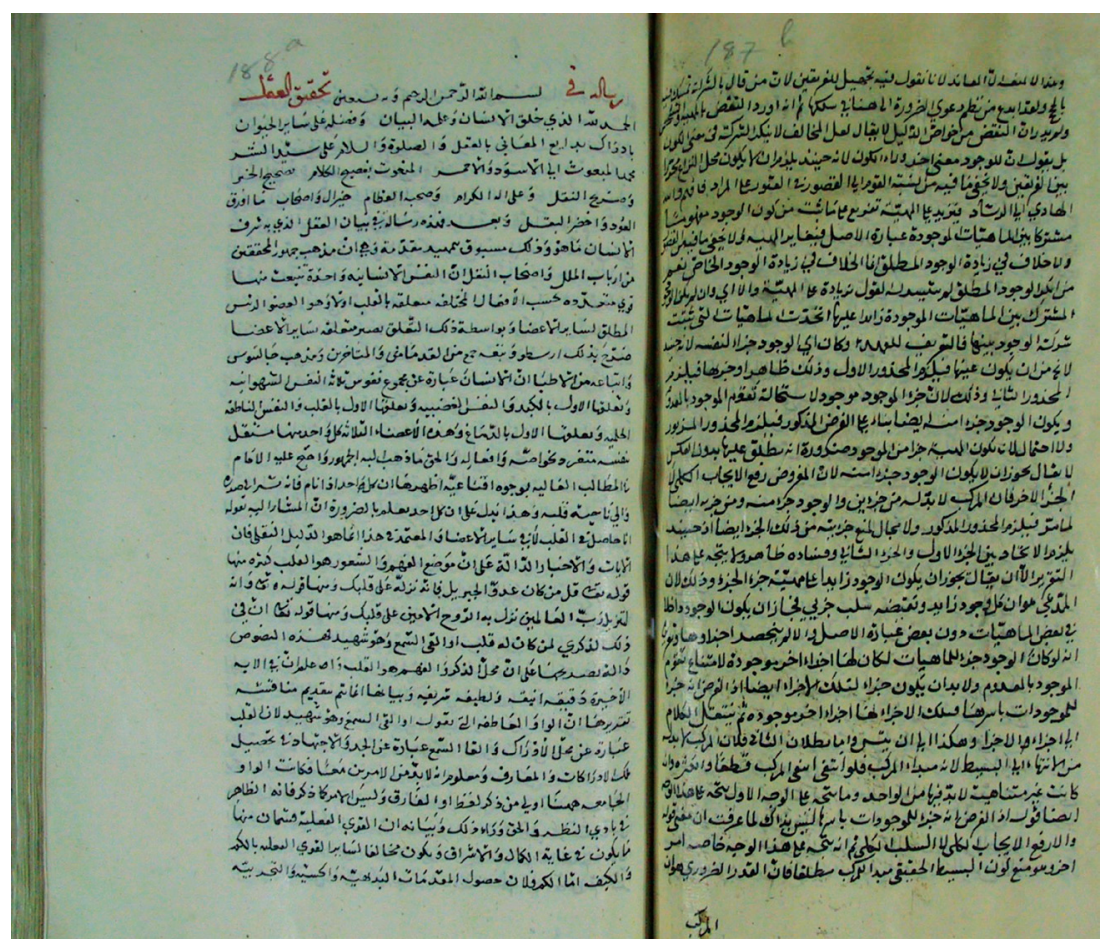


4) Topkapı Sarayı Museum, Revan Köşkü, n. 2022

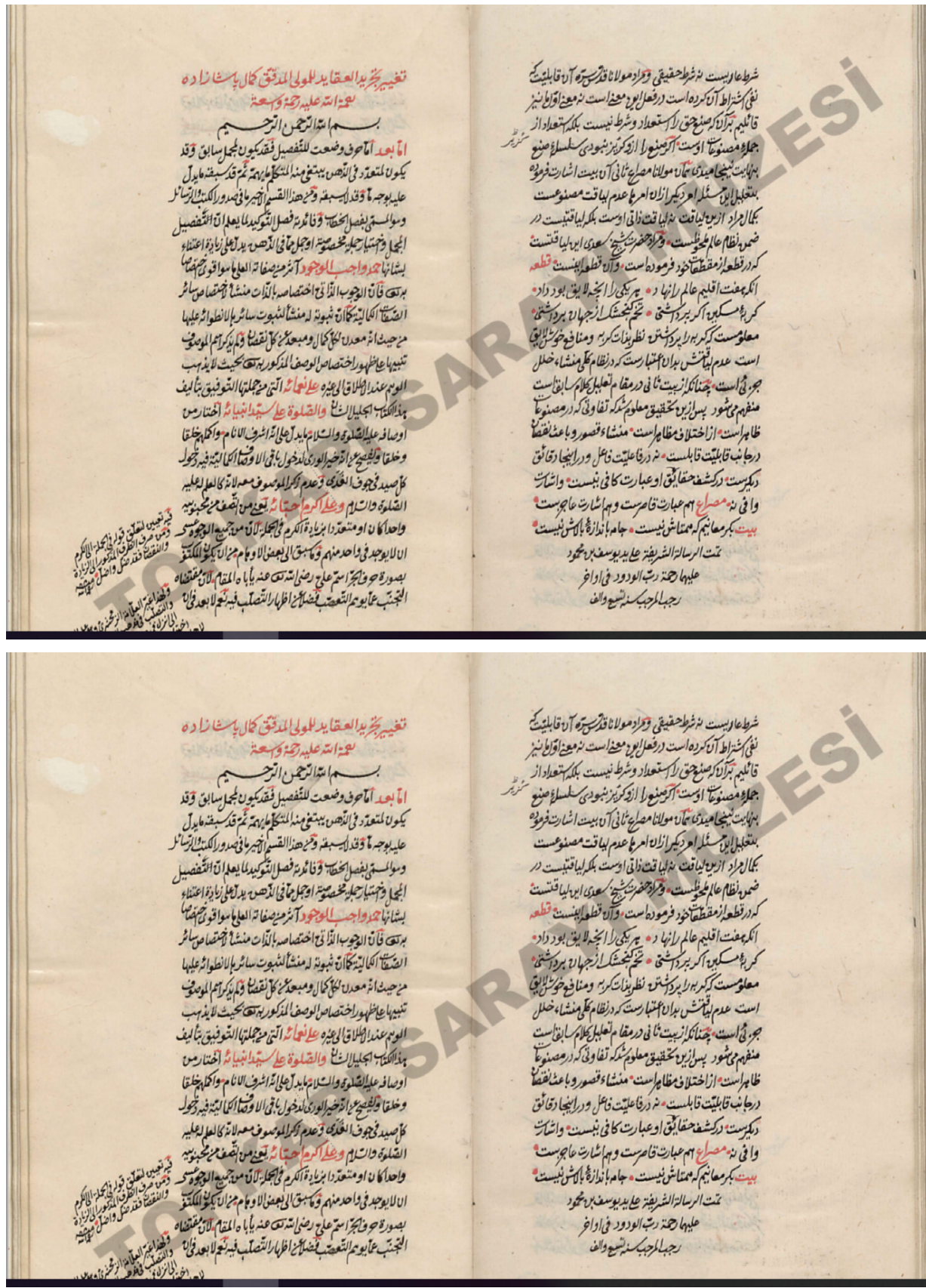


5) Süleymaniye Library, Bağdatlı Vehbi, n. 2041
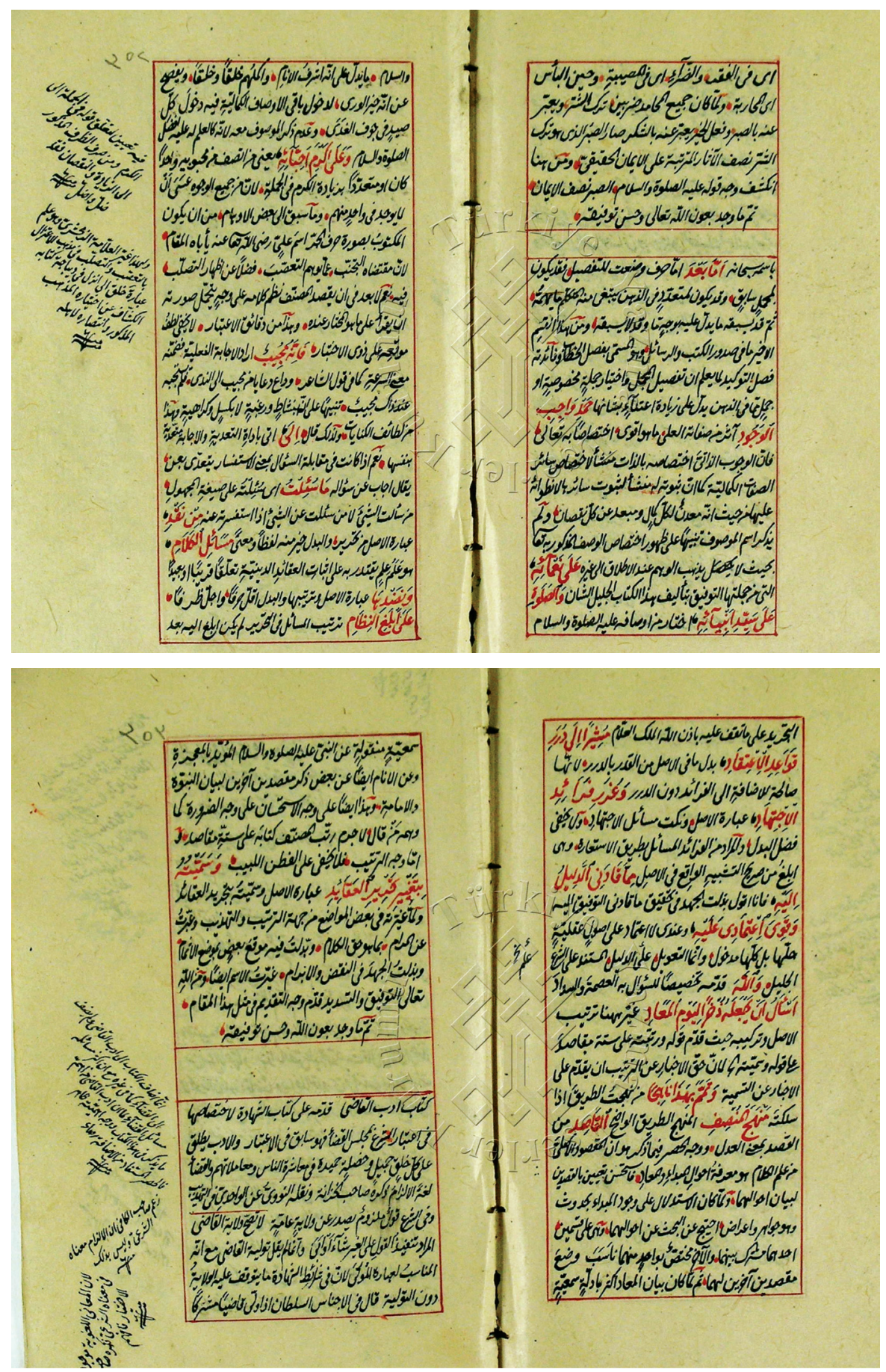
6) Süleymaniye Library, Murat Molla, n. 1834
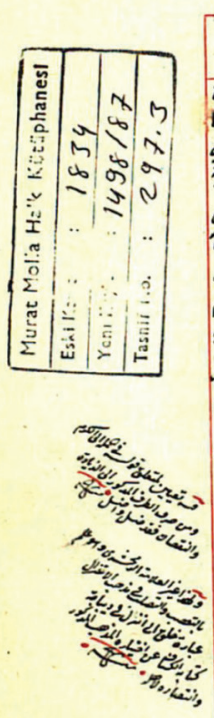

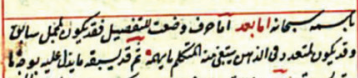

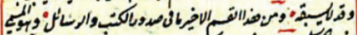

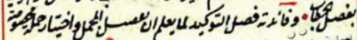

|

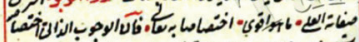

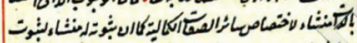

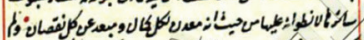

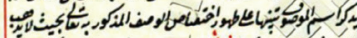

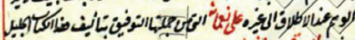

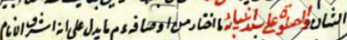

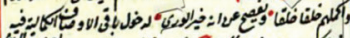
>

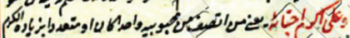
ن بخان

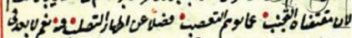

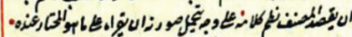

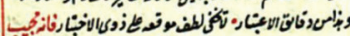

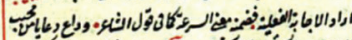

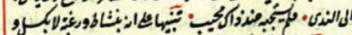

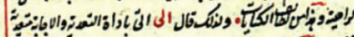
نتسبا.
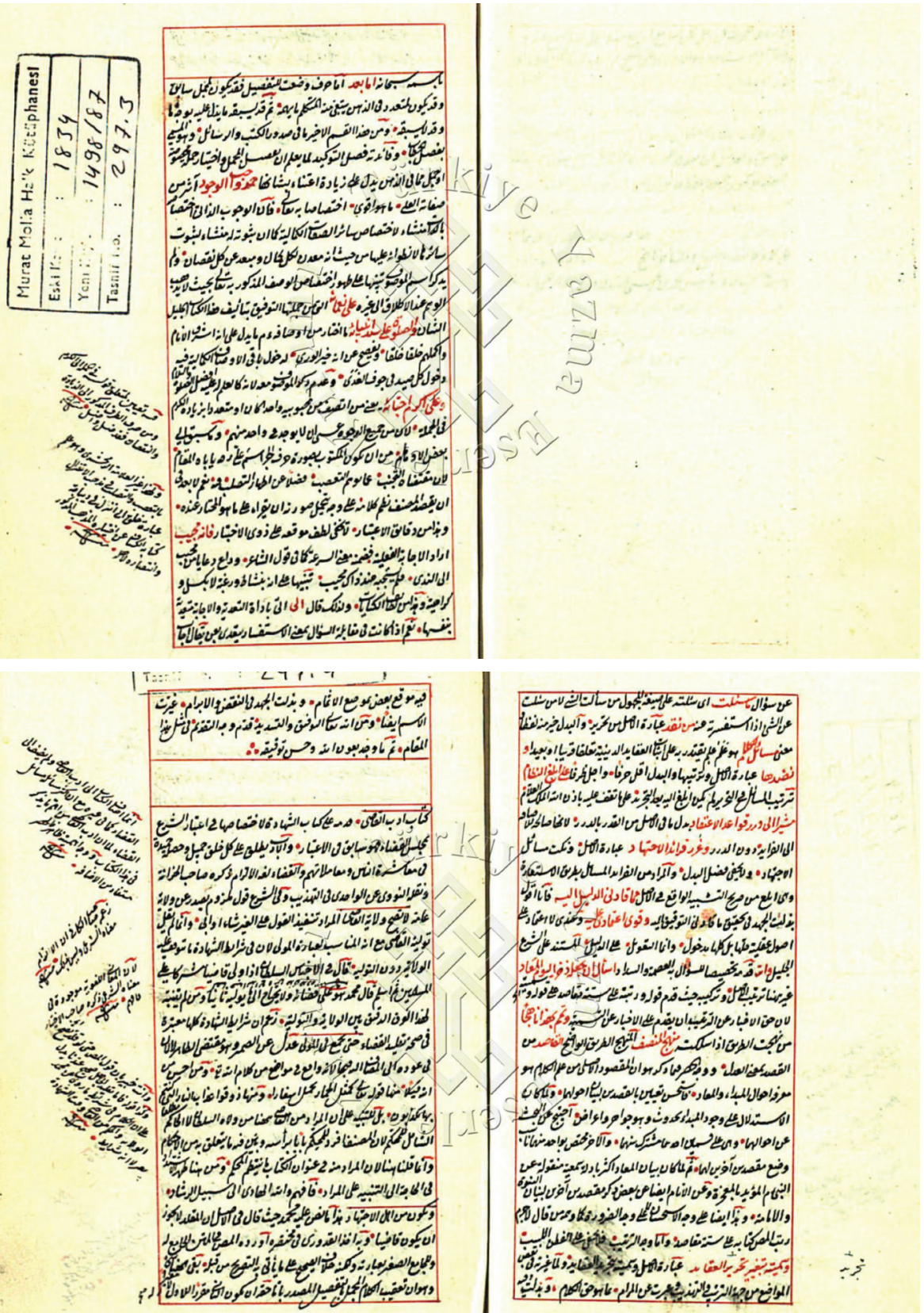

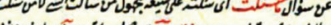

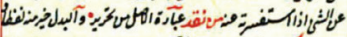

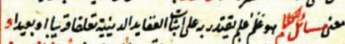

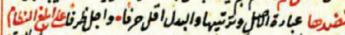

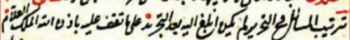

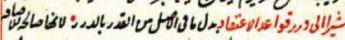

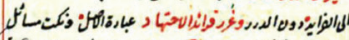

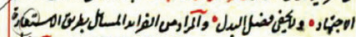

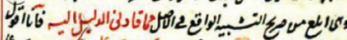

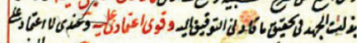

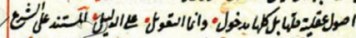

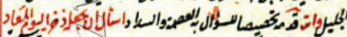

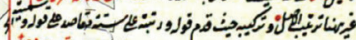

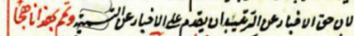

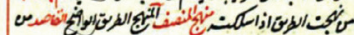

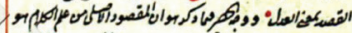

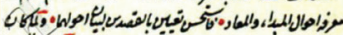

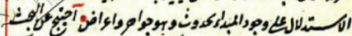

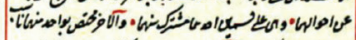

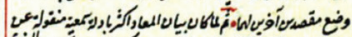

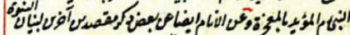

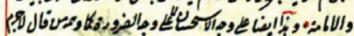

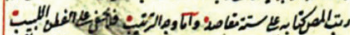

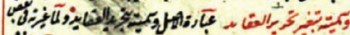

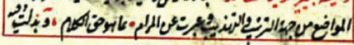

